\title{
HOW ANTITRUST REALLY WORKS: A THEORY OF INPUT CONTROL AND DISCRIMINATORY SUPPLY
}

\author{
Ramsi A. Woodcock ${ }^{*}$
}

\begin{abstract}
Antitrust law and policy today are a semi-coherent welter of legal and economic doctrines. Immanent in them, however, is a structure of great simplicity and utility. The concept at the heart of the antitrust laws is the linear supply chain, consisting of an essential input, a downstream market in which competition is harmed through the discriminatory supply of the input to downstream firms, and consumers who pay higher prices for finished products as a result of the discriminatory behavior. Antitrust attacks this problem of the discriminatory supply of inputs in two ways. First, it seeks to prevent any one intelligence from taking control over the input, because absent such centralized control, competition from input suppliers eliminates any attempt at discrimination. Stopping the centralization of control over inputs is not always possible, however, because sometimes centralized control improves the quality of the input, and antitrust follows an implicit rule of "innovation primacy," which holds that any act that plausibly improves the product likely does more good for consumers than any resulting increase in prices harms them, and so the act must be immune from antitrust scrutiny.

Second, antitrust regulates attempts by input controllers to use their power to increase their profits other than by charging what they know to be the highest possible prices for their products given their level of knowledge of consumer willingness to pay. Profits can be increased in this way by only three routes, each of which involves discrimination by the input controller in the supply of inputs to downstream firms. The input controller can discriminate in favor of firms that improve the final product ultimately sold to consumers and so increase consumers' willingness to pay. The input controller can discriminate in favor of downstream firms that supply the input controller with information about consumer willingness to pay, enabling the input controller better to choose its prices to maximize its profits. And the
\end{abstract}

\footnotetext{
* Assistant Professor, University of Kentucky Rosenberg College of Law, Secondary Appointment, Department of Management, University of Kentucky Gatton College of Business \& Economics. This research was supported by a grant from the John S. and James L. Knight Foundation. Felix Chang, Fiona Scott Morton, John Newman, Menesh Patel, and Samuel N. Weinstein provided helpful comments.
} 
input controller can discriminate against downstream firms that refuse to give the input controller access to profits that the firms have in turn extracted from consumers. The doctrine of innovation primacy protects discrimination that improves the final product sold to consumers, but not discrimination that facilitates information acquisition or the disciplining of refractory downstream firms.

This analysis resolves numerous longstanding conundrums in antitrust, including (1) whether antitrust picks winners (it must), (2) whether picking winners limits consumer sovereignty (impossible, because whenever a firm discriminates in the supply of inputs, the firm picks winners, and antitrust, which does no more than challenge such discrimination, therefore only ever substitutes its judgment for that of firms, never for that of end consumers), (3) whether antitrust should have a monopoly power requirement (it should, but the requirement should apply to the input market and not, as at present, to the downstream market in which competition is harmed), (4) whether firms should be allowed to compete on their own platforms as a general matter (of course they should, unless it is thought that consumers always know better than firms how everything they buy should be made, from start to finish), and (5) how to define the limits of the firm (the boundary of the firm does not end where formal ownership ends, but rather where discrimination in the supply of inputs ends). The analysis also shows why Lorain Journal, Aspen Skiing, Linkline, Trinko, Microsoft, Qualcomm, exclusive dealing, and tying are all the same basic case. 
Table of Contents

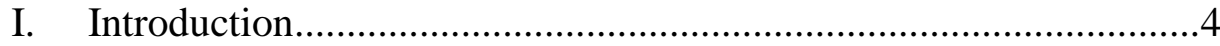

II. Power and Antitrust .....................................................................

III. The Acquisition of Power .................................................. 7

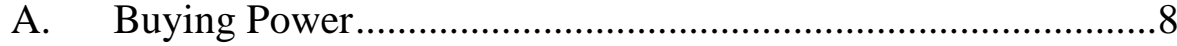

1. Buying Suppliers, Not Supplies................................................8

2. Only Mergers That Do Not Improve Products Are Prohibited.....8

3. The Rule of Innovation Primacy.................................................9

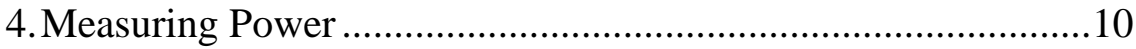

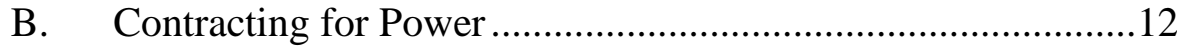

1.The Rule of Reason and the Per Se Rule ..................................12

2. The Definition of Agreement in Antitrust and the Problem of Tacit

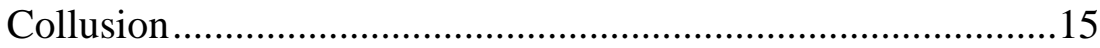

C. Creating Power ..................................................................16

D. The Tech Giants' Acquisition of Power.................................17

IV. The Exercise of Power .............................................................18

A. Theory ....................................................................... 18

1. Maximizing Profits Consistent with Willingness to Pay ............18

2.Expanding Willingness to Pay ................................................20

3. The Role of Discrimination in the Supply of Inputs in Expanding Willingness to Pay ................................................................21

4. Whether to Permit Discrimination as a Choice between Letting the Input Controller Decide How to Make the End Product and Letting End Consumers Decide How to Make the End Product .............26

5.A Product Is Defined by the Ambit of an Input Controller's

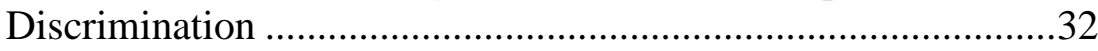

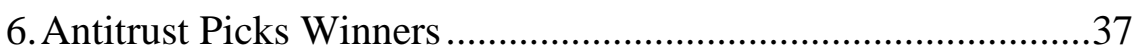

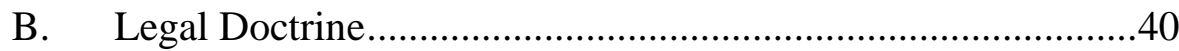

1. The Law of Monopolization ....................................................40

2.Predatory Pricing ...................................................................55

3.Exclusive Dealing, Microsoft, and Google ...............................57

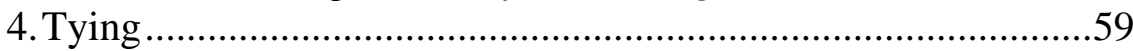

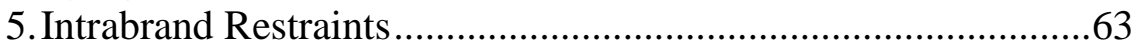

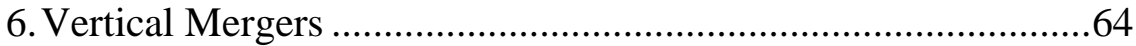

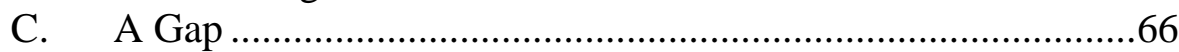

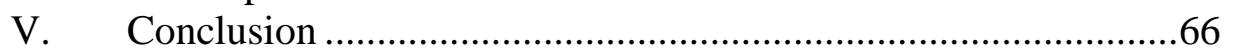




\section{INTRODUCTION}

There is very little in antitrust doctrine or antitrust economics that provides guidance about when an antitrust case can be brought or when it will be won. In the area of single-firm conduct, for example, the only definitive guidance from the courts is that (1) willful acquisition or maintenance of (2) monopoly power is illegal. ${ }^{1}$ But what is willful acquisition? Antitrust economists answer that it is conduct that reduces consumer welfare, that incalculable quantity that can be imagined only by shoehorning market reality into curves of supply and demand and then pretending that nothing else matters. ${ }^{2}$

The shortcomings of doctrine and economics are not, however, the shortcomings of actual practice, in which can be spied a structure in factpatterns and outcomes not reflected in either the law or the economics of the field. The structure has two pillars. The first is that control over an input essential to production is the ultimate source of all commercial power and the core interest of the antitrust laws. Indeed, antitrust can be divided into two main preoccupations, which do not split neatly along the lines of the Sherman Act's distinction between concerted conduct (Section 1) and solitary conduct (Section 2): regulation of the acquisition of power through centralization of control over an input and regulation of the exercise of power through discrimination in the manner of supply of that input to downstream firms. ${ }^{3}$

A taste of the utility of this approach may be had in the answer it provides to the question what constitutes willful acquisition of power. The answer is that it is discrimination-facial or by disparate impact - in input supply: the favoring of some downstream firms over others. Discrimination results in a substitution of the input controller's discretion over how the final product sold to consumers is to be made for the discretion of consumers themselves, for it is consumers who otherwise determine which firms get the inputs by using their purchases to strengthen those who use the inputs better. In substituting seller control for buyer control, discrimination undermines the consumer sovereignty that is the value proposition of the free market and therefore attracts antitrust's gaze.

The second pillar is what I call innovation primacy: the observation that courts do not condemn either the acquisition or exercise of power when there

\footnotetext{
${ }^{1}$ See United States v. Grinnell Corp., 384 U.S. 563, 570-71 (1966).

${ }^{2}$ See Robert D. Willig, Consumer's Surplus Without Apology, 66 AM. ECON. Rev. 589, 589 (1976).

${ }^{3} 15$ U.S.C. §§ 1, 2 (2018).
} 
is a plausible case to be made that the conduct improves the end product sold to consumers, regardless what effects the conduct has on competition. ${ }^{4}$ These two pillars explain outcomes in a broad range of major cases, for in each the plaintiff's case can be summed up as either an objection to centralization of control over inputs or to their discriminatory supply, and the case outcome can be shown to turn on whether the court ultimately thought the conduct made the product better.

This analysis shows that latent in antitrust there is a coherent and, importantly, a judicially-administrable system in which judges rely ultimately on intuition to pick winners whenever it appears that a firm is about to cement control over an input or use pre-existing control to impose its will on the supply chain regarding how a product is to be made. The judge steps in and substitutes his own view for that of the firm regarding what makes a better product. If this makes antitrust sound radically interventionist, that is because antitrust is radically interventionist. Power is an essential part of all production, because one of the things consumers want from a market is the luxury of not deciding in full how a product is to be made, and so sellers must decide how at least part of every product is assembled. Antitrust cannot therefore apply the neutral principle that all power is to be eliminated. And so antitrust can act only by deciding between good acquisitions or exercises of power-good product choices - and bad acquisitions or exercises of power - bad product choices. Judges often hide behind economic expertise in making these determinations, but at the end of the day no one knows what makes a better product: it is a value judgment the ultimate responsibility for which lies with the court.

Part II develops the relationship between power and input control and introduces a basic conceptual diagram of the structure of antitrust that will reappear in different forms throughout the article. Part III describes the theory and practice of antitrust's regulation of the acquisition of power. Part IV does the same for antitrust's regulation of the exercise of power.

\section{Power AND ANTITRust}

All economic power springs from want, and specifically from the possession of something that someone else wants but cannot easily obtain elsewhere. ${ }^{5}$ The more the subordinate party needs the item, and the harder it

\footnotetext{
${ }^{4}$ See Ramsi A. Woodcock, The Obsolescence of Advertising in the Information Age, 127 YALE L.J. 2270, 2313-14 (2018).

${ }^{5}$ See Ramsi A. Woodcock, The Contrasting Approaches to Power of the Modern State and the Antitrust Laws: Lessons for Platform Regulation (2020), https://papers.ssrn.com/sol3/papers.cfm?abstract_id=3704450.
} 
is to find an alternative, the greater the power of the party that holds the thing. ${ }^{6}$ Thus in antitrust, a field devoted to the regulation of private power, a single conceptual apparatus governs every claim. ${ }^{7}$ In it, there is always some item, call it an input, that is under the control of the defendant, and there is always some other firm, not always a plaintiff, that needs the input to do something productive, and consequently has come under the power of the defendant. ${ }^{8}$ The goal of the antitrust laws is to prevent such power from arising, unless it is incident to conduct that can benefit the public, and if it is incident to conduct that can benefit the public, then to prevent the firm from exercising the power in ways that harm the public. ${ }^{9}$ That is, the antitrust laws regulate the acquisition of power and the exercise of power with a view to maximizing the welfare of the public, as opposed to the private welfare of firms.

The part of antitrust that governs the acquisition of power focuses upon control over the input, striving to prevent firms from acquiring so much control as to be able to deny downstream firms that need the input alternatives to dealing with the controller. In a market for eraser-tipped pencils, that means that antitrust is concerned with ensuring that no one firm acquires so much control over erasers that pencil manufacturers must deal with the firm in order to obtain erasers. For once that happens, a power relationship is born, one that places the pencil makers in the subordinate position. Antitrust rules governing contracts and mergers between competitors are concerned with the acquisition of power, as are rules governing contracts between different levels of the supply chain - between those who make the input and those who need it, for example - when they serve to centralize control over the input in the hands of a single profit-maximizing intelligence. ${ }^{10}$

The part of the antitrust laws that governs the exercise of power focuses on the terms that a firm that has acquired power already may impose upon those who need the input, and in particular on the consequences of those terms for buyers further downstream - the buyers who buy from the firm that

\footnotetext{
${ }^{6}$ See id., https://papers.ssrn.com/sol3/papers.cfm?abstract_id=3704450.

${ }^{7}$ See Phillip E. AREeda \& Herbert Hovenkamp, Antitrust LaW: An Analysis of ANTITRUST PRINCIPLES AND THEIR APPLICATION IIII 260b, 260c (4th ed. 2020) (noting that antitrust's goal is not to regulate noncommercial affairs).

${ }^{8}$ Antitrust seems most aware of the importance of inputs to its claims in the context of refusals to deal and exclusive dealing agreements. See Herbert HovenKamp, Federal ANTITRUST POLICY, THE LAW OF COMPETITION AND ITS PRACTICE 381-406, 564-65 (6th ed. 2020). But one claim of this Article is that in fact input denial lies at the heart of the entire field.

${ }^{9}$ The qualification in antitrust that conduct is not to be proscribed when it benefits the public is known as the "rule of reason." See Board of Trade of Chicago v. United States, 246 U.S. 231, 238 (1918).

${ }^{10}$ See 15 U.S.C. $§ 1,18$ (2018).
} 
has fallen directly under a controller's power-and ultimately for the consuming public at the end of the supply chain. In a market for pencils, that means that antitrust is concerned with preventing a firm that controls erasers from using that power to extract value from buyers in ways that ultimately harm pencil users, rather than just the pencil manufacturers that buy the erasers. Antitrust's prohibitions on monopolization, tying, and some contracts and acquisitions between different levels of the supply chain are all concerned with exercises of power. ${ }^{11}$

The basic scheme of antitrust may therefore be represented by the

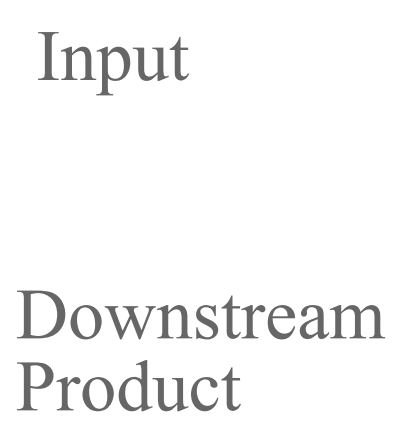

Consumers

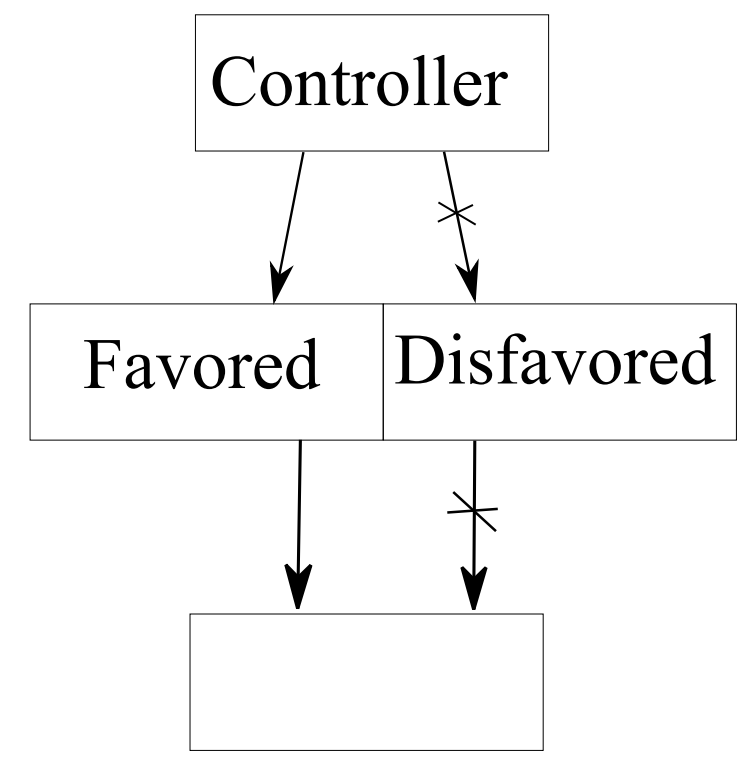

Figure 1

illustration in Figure 1. The figure shows that firms strive to acquire power by taking control of the market for a particular input. Once a firm controls an input, the firm uses denial of access to the input to exercise its power over downstream firms, favoring some and disfavoring others, and ultimately determining which downstream products consumers can access and which they cannot.

III. THE ACQUISITION OF POWER

\footnotetext{
${ }^{11}$ See 15 U.S.C. $§ 1,2,14$ (2018).
} 


\section{A. Buying Power}

1. Buying Suppliers, Not Supplies

The antitrust laws regulate the acquisition of power by striving to prevent any one intelligence from obtaining enough control over inputs to permit that intelligence to dictate terms to those who want the input, unless the control enables the intelligence to make the input better in the sense of better able to contribute to maximizing the value of the end product sold downstream to consumers. One important way in which a firm may obtain control over inputs is through purchases. But the sort of purchases required to succeed at obtaining control are not purchases of the inputs themselves but of the firms that make them. Purchasing inputs is futile, because the firms that make them can always make more, forever frustrating any attempt to control all inputs. ${ }^{12}$ So too are purchases of the machinery used to make inputs, for more of the machinery, too, can be made. ${ }^{13}$ Purchasing the firms that make the inputs is different, because along with such going concerns comes knowledge and experience that are very difficult to reproduce from outside of the market. ${ }^{14}$ Those who know about the market, are interested in being in the market, and who know enough about the production process - from where to find supply to where to find customers - to survive in the market, are always few and generally already in the market, operating the firms that are there. ${ }^{15}$ Buy those firms, and the likelihood that new firms interested in producing the input will quickly enter is low, ensuring that the purchases result in true input control.

\section{Only Mergers That Do Not Improve Products Are Prohibited}

Antitrust's rules governing the acquisition of power through purchases therefore regulate the purchase of input suppliers or the acquisition of their productive assets, rather than the purchase of the inputs that suppliers produce. ${ }^{16}$ Antitrust does not, however, prohibit such acquisitions outright,

\footnotetext{
12 See Edith Penrose, The Theory of the Growth OF The Firm 40 (1995); AreedA \& HOVENKAMP, supra note 7, III 1202b, 1202c (stating that "there is nothing durable about the situation").

${ }^{13}$ See PENROSE, supra note 12, at 40; HoVENKAMP, supra note 8, ๆ 1202d2 ("So long as the plant seller remains in the business of supplying that product, however, the plant transfer does not deprive other customers of a source of supply ....').

${ }^{14}$ See PENROSE, supra note 12, at 40-50.

${ }^{15}$ See id.

${ }^{16}$ See HovENKAMP, supra note 8, $\uparrow 1202$ a (noting that the core concern of antitrust's merger rules is the acquisition of "going concerns"). There is, however, some authority for the proposition that buying up all of the output in the input market would violate either antitrust's merger rules or its monopolization rules, particularly where the input is intellectual property.
} 
for antitrust is not a rule against power, but rather a rule against unnecessary power or a rule against power that is not incident to some productive activity that ultimately benefits the public understood as end consumers. ${ }^{17}$ Antitrust therefore asks first whether a merger is likely to lead to enough power for a firm to raise prices unilaterally on buyers (so-called unilateral effects analysis) or whether the merger is likely to so reduce the number of firms in the industry that they will start to behave toward one another as neighbors behave in a small town: politely and in a spirit of tacit mutual aid (coordinated effects analysis). ${ }^{18}$ Such tacit collusion can have the same effect as actual coordination between firms, and coordination is a form of centralization of control as it implies that firms are acting together in their mutual self-interest as if they were led by a single intelligence. ${ }^{19}$ Thus antitrust fears not only the merger that gives the merged firm so much power that it can raise prices unilaterally, but also the merger that facilitates tacitly or even explicitly coordinated behavior, on the theory that the smaller the number of firms in the industry the easier it is for them to coordinate. If it turns out that the merger will have such unilateral or coordinated competitive effects, meaning that the merger will lead to such a centralization of control over inputs that the merged firm can raise prices, the court then considers whether the merger is nevertheless necessary to improve the quality of the product offered to buyers. $^{20}$

\section{The Rule of Innovation Primacy}

The courts here, as everywhere in antitrust when the courts evaluate product quality, would prefer to balance the probable increase in price against the probable increase in quality. ${ }^{21}$ But in practice the courts do no such thing. Instead, the courts apply a rule that I call "innovation primacy": so long as the defendant makes a credible case that the action will improve the product, the courts will permit the action, even if it could lead to higher prices or even prices that would more than offset the gains consumers enjoy due to the

See id. III 702c, 768a4, $1202 \mathrm{f} 4$.

${ }^{17}$ See Board of Trade of Chicago v. United States, 246 U.S. 231, 238 (1918).

18 See Andrew I. Gavil ET AL., Antitrust LaW in Perspective: CaSes, Concepts, And PROBLEMS IN COMPETITION POLICY 774-75, 799-802 (3d ed. 2017).

${ }^{19}$ See HovENKAMP, supra note 8, at 659-60.

${ }^{20}$ See Oliver E. Williamson, Economies as an Antitrust Defense: The Welfare Tradeoffs, 58 AM. ECON. REV. 18, 21 (1968) (making this point in terms of process innovation rather than product innovation); Ramsi A. Woodcock, Inconsistency in Antitrust, 68 U. MIAMI L. REV. 105, 126-36 (2013) (updating the Williamson diagram in product innovation terms); HOVENKAMP, supra note 8, at 638-49.

${ }^{21}$ See C. Scott Hemphill, Less Restrictive Alternatives in Antitrust Law, 116 COLUM. L. REV. 927, 934 (2016). 
product improvement. ${ }^{22}$ The reason is that economists generally see innovation as the primary source of growth in the economy, far more important than the increases in production and consumption that come from offering unimproved products at lower prices. ${ }^{23}$ And courts fundamentally, and probably wisely, mistrust the ability of economists accurately to measure the benefits of innovation and to compare them with the costs to consumers of higher prices, so the courts reduce the balancing test to a binary question: does the merger credibly improve the product or not? ? $^{24}$

The failure to take price effects into account in individual cases in which innovation is present means that in individual cases consumers can be harmed if price increases exceed quality improvements in value to consumers. ${ }^{25}$ But this is not to say that antitrust's consumer welfare standard, which holds that antitrust should seek to prevent harm to consumers, rather than harm to the overall economy, including both producer and consumer welfare, does not apply. ${ }^{26}$ Antitrust employs innovation primacy because it believes that on average quality improvements deliver more value than price increases take away. Moreover, consistent with the consumer welfare standard, antitrust will not approve conduct that increases prices but does not innovate, even if the price increase does not price buyers out of the market and therefore does not reduce total welfare. ${ }^{27}$

\section{Measuring Power}

Antitrust enforcers answer the threshold question whether a merger will give rise to power by applying the intuitive rule that a firm has power if the firm is able profitably to raise the price that the firm charges to buyers above the minimum required to cover the costs of production. ${ }^{28}$ In real world markets, in which each firm sells a product that is at least slightly differentiated from other products, and every product therefore has some

\footnotetext{
${ }^{22} \mathrm{Cf}$. id. at $947-48$.

${ }^{23}$ See, e.g., Kenneth J. Arrow, Workshop on the Economy as an Evolving Complex System: Summary, in THE ECONOMY AS AN EVOlving COMPLEX System 275, 281 (Philip W. Anderson et al. eds., 1988) ("Innovations . . . are one of the least analyzed parts of economics, in spite of the verifiable fact that they have contributed more to per capita economic growth than any other factor.").

${ }^{24}$ Cf. Hemphill, supra note 21, at 947-48.

${ }^{25}$ See Woodcock, supra note 20, at 126-36.

${ }^{26}$ See John B. Kirkwood \& Robert H. Lande, The Fundamental Goal of Antitrust: Protecting Consumers, Not Increasing Efficiency, 84 NOTRE DAME L. ReV. 191, 197-201 (2008).

${ }^{27}$ See Carl Shapiro, Antitrust Limits to Patent Settlements, 34 RAND J. ECON. 391, 396 (2003).

${ }^{28}$ See John B. Kirkwood, Market Power and Antitrust Enforcement, 98 B.U. L. REv. 1169, 1174-77 (2018).
} 
customers who prefer it above all others, every firm has at least some power over price. ${ }^{29}$ For no buyer has available an alternative that is identical to the firm's, and so every buyer must give something up if the buyer wishes to resist the firm's dictates and buy from a competitor, even in a market crowded with differentiated alternatives. ${ }^{30}$ Courts therefore impose a screen on this market power test, and consider firms to have power if their ability to profitably increase prices is substantial. Usually, the required price increase is $5 \% .^{31}$

Courts and economists like to indulge the fantasy that this is a problem that can be definitively answered through quantitative economic analysis, but it never can be. There is rarely data available to establish power to raise prices directly and so instead courts embark on what can only be described as pseudo-economics: the indirect inquiry into power known as "market definition." 32 According to this approach, a firm has power profitably to raise price if the firm has a large share of a properly-defined relevant market. This is pseudoscience in part because there is no economic basis for supposing that a firm with a large market share can raise price. That depends on whether competitors are able to expand output or enter the market in response to a price increase, not on market share. ${ }^{33}$

Markets are defined by whether a $5 \%$ increase in price of all the products in the market would be profitable for the market. ${ }^{34}$ If not, the argument goes, one must find the next closest substitute to the products in the market, add that substitute in with the rest, and test whether a 5\% increase in price of all the products in that expanded group of products would in aggregate be profitable for the owners of that expanded group. ${ }^{35}$ The process continues until a group of products for which a price increase is profitable is found. ${ }^{36}$ Of course, one cannot start with a single product market consisting of the merged firm's product alone, for then the exercise would require a direct inquiry into whether the firm can profitably raise price, and so one starts with the firm's product plus the product felt to be the closest substitute of the

29 See Edward H. Chamberlin, The Theory of Monopolistic Competition: A ReORIENTATION OF THE THEORY OF VALUE 71-73 (7th ed. 1958).

${ }^{30}$ See id.

${ }^{31}$ See HovenKAMP, supra note 8, at 112-13.

${ }^{32}$ Cf. Herbert Hovenkamp, The Looming Crisis in Antitrust Economics, No. ID 3508832, 14 (2020) ("E]conomics has made significant strides in the last two decades in measuring market power directly from observed transactional behavior.").

${ }^{33}$ See William J BAUMOL ET AL., CONTESTABle MARKETS AND THE THEORY OF INDUSTRY STRUCTURE (1988).

${ }^{34}$ See HovenKAMP, supra note 8 , at 112-13.

35 See id.

${ }^{36}$ See id. 
defendant's product. The question which products to test as substitutes is ultimately arbitrary, based on the market sense of enforcers. One sees however in the avoidance of own-product markets the real rationale for the market definition approach, which is that it is easier to find a reliable signal of power in the price movements of multiple products than in the noisy movements of the price of a single product, and so market definition is more tractable than direct proof of monopoly power.

The inquiry into power addresses the unilateral conduct problem, but the coordinated effects problem requires more. In theory one would want to predict the competitors with which the merged firm might collude, and determine their combined power, offset by their ability to cooperate and act as a single intelligence. But that is too hard, and courts tend to focus instead on measures of market concentration, rather than just the market share of the merged firm. ${ }^{37}$ The courts generally treat mergers that lead to combined market shares and concentration changes in excess of certain limits as presumptively unlawful. This "structural presumption" can be attacked directly with evidence that competition could come from outside the market or that competition could easily increase output in response to any price increase. ${ }^{38}$ If it cannot be undermined in this way, then only the aforementioned evidence that the merger improves the product will save the merger.

\section{B. Contracting for Power}

1. The Rule of Reason and the Per Se Rule

Mergers are a way of acquiring power through the exercise of property rights and the law of agency, with perhaps an assist from the natural human tendency to cooperate when the number of one's neighbors is few and mutual interest is clear. The merger itself brings the assets of the merging firms under the control of a single firm with a single management. The law of agency requires that the human beings operating the assets do so with the sole, common goal of maximizing the profits of the firm. ${ }^{39}$ And neighborliness causes other firms in the industry to collude tacitly with the merged firm,

\footnotetext{
${ }^{37}$ See United States v. Philadelphia Nat. Bank, 374 U.S. 321, 363-64 (1963).

${ }_{38}$ See United States v. Philadelphia Nat. Bank, 374 U.S. 321; United States v. General Dynamics Corp., 415 U.S. 486 (1974); US v. Baker Hughes Inc., 908 F. 2d 981 (D.C. Cir. 1990).

${ }^{39}$ See Donald C. Langevoort, Agency Law inside the Corporation: Problems of Candor and Knowledge Sixteenth Annual Corporate Law Symposium: Agency Law inside the Corporation, 71 U. CIN. L. REv. 1187, 1191-92 (2002-2003).
} 
further centralizing control over the inputs the industry produces. ${ }^{40}$

Control over an input may also be centralized in the hands of a single intelligence through the use of contracts. The most obvious way this happens is the price-fixing agreement, pursuant to which a group of firms agree to maximize their joint profits, effectively bringing them all under the control of a single intelligence dictating the same terms to all buyers. ${ }^{41}$ But agreements on other things, such as the level of quality at which to offer products, or not to sell to particular buyers, also reflect a centralization of control with respect to those characteristics. As in the case of mergers, antitrust prohibits price-fixing, and, more generally, any agreement between firms selling the same input, only if the conduct does not improve the products offered by the firms. ${ }^{42}$ A joint venture between two companies to develop new clean fuel technology would pass muster, for example, even though the result would be a product that only the two companies would be able to offer, giving both power over buyers, because the technology would represent a product improvement. ${ }^{43}$ Antitrust consideration of an agreement also requires, as in the merger context, consideration of whether the parties collectively control enough of the input to be able profitably to raise prices, an inquiry known as "market power" in this context. Thus the clean fuel joint venture might also escape liability were the combined market share of the joint venturers to fall below about $35 \%$, the minimum share generally thought necessary for market power to exist. ${ }^{44}$ (Direct proof is also permitted, however.)

The inquiry into product improvement and the market power requirement collectively are known as the "rule of reason" in contracting cases. ${ }^{45}$ But the inquiry itself appears in outline throughout antitrust. ${ }^{46}$ We have encountered it already in the merger context and will see shortly that it is almost identical to the basic monopolization claim that underlies all of the antitrust law governing exercises of power. ${ }^{47}$ But antitrust occasionally departs from the basic inquiry into product improvement and power and instead will ban a

${ }^{40} C f$. AVINASH K DiXit ET AL., GAMES OF STRATEGy (2010).

${ }^{41}$ See Michael D Whinston, LeCtures ON ANTITRUSt ECONOMics 15-57 (2008).

${ }^{42}$ See Broadcast Music, Inc. v. Columbia Broadcasting System, Inc., 441 U.S. 1, 19-20 (1979).

${ }^{43}$ See HovenKamP, supra note 8, at 288-95.

${ }^{44}$ See 1 aBA Section of ANTITRUSt Law, ANTITRUST Law DeVElopMENTS 66 (6th ed. 2007).

${ }^{45}$ See Timothy J. Muris, The New Rule of Reason, 57 AnTITRUST L.J. 859, 861-64 (1988);

Hemphill, supra note 21, at 938.

${ }^{46}$ See Hemphill, supra note 21, at 938-39.

${ }^{47}$ See infra Part IV.B. 
practice without a showing of either. This is called the per se rule. ${ }^{48}$ In the context of acquisitions of power through contract, antitrust applies the per se rule only against naked price fixing agreements, meaning those that have no rationale other than to fix prices. ${ }^{49}$ Thus the clean fuel joint venture agreement escapes the per se rule, and can be condemned only upon a showing of a lack of product improvement and the existence of market power, because it has, at least superficially, a product improvement rationale. ${ }^{50}$ By contrast, an agreement between two pencil companies not to charge less than $\$ 1$ per pencil, absent more, is simply illegal. ${ }^{51}$ Indeed, although all antitrust claims may be charged as crimes, prosecutors only ever bring criminal cases against such naked price fixing agreements. ${ }^{52}$ (We shall encounter per se rules again, though in somewhat moribund form, in the antitrust law of power exercises. ${ }^{53}$ )

A firm seeking to obtain control over all the inputs in a market does not itself need to be a producer in that market, and in this case the firm will not centralize control through what antitrust calls a horizontal dealing-a dealing, whether in the form of merger or contract, between firms that compete in the same market to supply the input. ${ }^{54}$ In this case, the coordination takes place through either conglomerate or vertical dealing instead. In conglomerate dealing, the intelligence centralizing control lies outside of the target input market and also outside of the supply chain: it is not a player in the market fed by the input, for example. ${ }^{55}$ But much more often the intelligence centralizing control is in the supply chain, in which case the dealing is vertical. ${ }^{56}$

Antitrust applies the same rules to conglomerate dealings — whether via merger or via contract - that it applies in the horizontal merger or contract context. If a merger, the antitrust laws will permit an initial acquisition (unless currently-moribund rules against vertical mergers spring back to life), but antitrust will treat multiple acquisitions in the same market as a horizontal merger, implemented through a hub purchaser standing outside of the market. ${ }^{57}$ Similarly, antitrust recognizes that parallel agreements with a hub outside of the market have the same effect as a horizontal agreement between

\footnotetext{
48 See Arizona v. Maricopa County Medical Soc., 457 U.S. 332, 342-48 (1982).

${ }^{49}$ See HovENKAMP, supra note 8, at 248-50.

${ }^{50}$ See id. at 260-71.

${ }^{51}$ See id. at 248-49.

${ }^{52}$ See GAVIL ET AL., supra note 18, at 1292.

${ }^{53}$ See infra Part IV.B

${ }^{54}$ See GAVIL ET AL., supra note 18, at 671.

55 See id.

${ }^{56}$ See id.

${ }^{57}$ See infra Section IV.B.6.
} 
the participants, and antitrust prohibits them on the famous hub-and-spoke theory of Interstate Circuit, Inc. v. United States. ${ }^{58}$

2. The Definition of Agreement in Antitrust and the Problem of Tacit Collusion

Antitrust does not only regulate the acquisition of power through formal, legally-enforceable contracts, but also regulates the acquisition of power through any sort of communication that suggests the existence of an agreement. Thus a knowing look caught on tape, or testimony by a participant in the scheme, neither of which would come close to creating a legallyenforceable agreement, could count as an agreement for purposes of the antitrust laws. ${ }^{59}$

This reflects antitrust's appreciation of the power of neighborly behavior by firms, the tacit coordination or tacit collusion, as it is often called in the literature, that we have already encountered in the law of mergers. Merger law tries to deter neighborly behavior by blocking mergers that lead to the sort of sparsely populated markets conducive to such conduct, but economists generally recognize that many markets already have so few players that tacit collusion is pervasive. ${ }^{60}$ The prevalence of sparsely populated marketsgenerally called concentrated markets in the literature-is not necessarily because antitrust does a bad job of blocking the mergers that reduce the number of firms in markets, but because larger firms often do make better products, or better products often make for larger firms. ${ }^{61}$ So firms often grow organically, through success, to dominate markets, or mergers that lead to domination cannot be blocked because they improve products.

Since it is not possible to prevent the creation of markets that are conducive to tacit collusion, antitrust wishes it could prohibit tacit collusion directly, at least when tacit collusion does not improve products. The likelihood that tacit collusion does improve products is quite small, because tacit colluders cannot engage in complex forms of cooperation any more than friendly neighbors can babysit for each other without speaking a word. A neighbor will avoid making loud noises without having to be told, and might collect your newspapers and packages when it looks as though you are away,

\footnotetext{
58 See Interstate Circuit, Inc. v. United States, 306 U.S. 208 (1939). The same rules apply when the hub is in the supply chain-indeed, the hub was in the supply chain in Interstate Circuit.

${ }^{59}$ See William E. Kovacic, The Identification and Proof of Horizontal Agreements under the Antitrust Laws Symposium on Tacit Collusion, 38 ANTITRUST BULL. 5, 8-9 (1993).

${ }^{60}$ See F. M Scherer \& DAVID Ross, Industrial MARKET STRUCTURE AND ECONOMIC PERFORMANCE 81-82 (3d ed. 1990).

${ }^{61}$ See id. at 98-102, 120-38.
} 
but little else is possible. Similarly, firms colluding tacitly can show respect for each other by not aggressively discounting prices, or not refreshing product lines too quickly (something that would force heavy expenditures in research and development), but they can hardly develop new technology jointly, as can be done by firms that collude via communication and therefore count as doing so via agreement.

But antitrust has been unable to prohibit tacit collusion directly, because it is hard to identify. ${ }^{62}$ Unlike mergers and agreements, which can be observed formally by finding a merger document or a suggestive communication between firms, tacit collusion ultimately exists only in the heads of the parties: it is a solipsistic activity. It can only at best be inferred by determining that a firm could have competed harder, but whether that is true requires the sort of fine business sense that courts profess to lack. ${ }^{63}$ And so antitrust uses an expansive definition of agreement to try to come as close to the line as possible, regulating any communication that suggests agreement. ${ }^{64}$ Purely parallel conduct, however, does not count. ${ }^{65}$

\section{Creating Power}

Merger, contract and tacit collusion are not the most important ways in which firms centralize control over inputs. The most important is the act of creation itself. Most firms obtain centralized control over an input by being the first to make it, or to understand its usefulness and incorporate it into an innovative product that consumers like. ${ }^{66} \mathrm{~A}$ firm is much more likely to control all of the eraser output in the market because the firm was the first to invent a low-cost method of making erasers, or because the firm was the first to start putting erasers on pencils, and needed a source of supply, than because the firm acquired all the eraser firms in the market or organized them into a cartel. ${ }^{67}$

\footnotetext{
${ }^{62}$ See HovenKAMP, supra note 8, at 219-20.

${ }^{63}$ See, e.g., Town of Concord, Mass. v. Boston Edison Co., 915 F. 2d 17, 25-28 (1st Cir. 1990).

${ }^{64}$ See GAVIL ET AL., supra note 18, at 311-15.

${ }^{65}$ See Theatre Enterprises, Inc. v. Paramount Film Distributing Corp., 346 U.S. 537, 540-42 (1954).

${ }^{66}$ See Frederic M. Scherer, First Mover Advantages and Optimal Patent Protection, $40 \mathrm{~J}$. TECH. TRANSFER 559, 559-60 (2015).

${ }^{67}$ Power obtained through innovation in this way, also called power derived from "organic growth" in the literature, is often associated with ownership, but that is not strictly necessary. A firm that is first to invent a product that requires a particular input may develop long-term contractual relationships, formal or informal, with suppliers that effectively give the firm control of the input to the exclusion of downstream competitors. See Lisa Bernstein, Beyond Relational Contracts: Social Capital and Network Governance in Procurement Contracts, 7
} 
As in all cases of centralization of control, the lock that innovation gives a firm over an input is usually due to the fact that knowledge is a very high barrier to entry. While an inventor may have patents that legally exclude competitors, there are many other reasons for which knowledge does not transfer easily, particularly in new markets in which few people have experience. $^{68}$ It will always be easier to buy from the incumbent input supplier than to make one's own input, just as it is always easier to "ask someone who knows" than to reinvent the wheel.

Antitrust today does not prohibit such organic acquisitions of power. Pursuant to the principle of innovation primacy, antitrust recognizes that they are the result of product-improving activity, and so although they may give rise to power, antitrust cannot condemn them. ${ }^{69}$ This was not always the case, however. In the mid- $20^{\text {th }}$ century, the courts nursed a line of cases that would have made organic growth illegal, most famously the Alcoa case in which the Supreme Court condemned Alcoa for increasing supply to meet demand. ${ }^{70}$ In recent years some have tried to rejuvenate this "effective competition" standard. ${ }^{71}$

\section{The Tech Giants' Acquisition of Power}

The tech giants' acquisition of power in their core markets appears to have been largely organic. Google's initial control over the search input is due to the superiority of its search algorithms. ${ }^{72}$ Facebook's initial control over social media - and the friend lists that come from that - appears to have been due mostly to a combination of luck and network effects: the fact that once a bunch of users had joined Facebook, the social network become more valuable to other users, who could find their friends there. ${ }^{73}$ Amazon's control over ecommerce appears to be due to its early development of a

\footnotetext{
J. LEGAL ANALYSIS 561, 566-72 (2015).

${ }^{68}$ See PENROSE, supra note 12, at 40-50.

${ }^{69}$ See AREEDA \& HovENKAMP, supra note 7, II 1202c (noting that acquisitions of inputs incident to internal growth do not violate antitrust's merger rules).

70 See United States v. Aluminum Co. of Am., 148 F. 2d 416, 430-31 (U.S. 1945); GAVIL ET AL., supra note 18 , at $488-89$.

${ }^{71}$ See Marshall Steinbaum \& Maurice E. Stucke, The Effective Competition Standard: A New Standard for Antitrust Symposium: Reassessing the Chicago School of Antitrust Law, 87 U. CHI. L. REV. 595 (2020).

${ }^{72}$ See Subcommittee on Antitrust, Commercial, and Administrative Law of the Committee on the Judiciary of the United States House of Representatives, Investigation of Competition in Digital Markets: Majority Staff Report and Recommendations 174 (2020).

73 See Fiona M Scott Morton \& David C Dinielli, Roadmap for an Antitrust Case Against Facebook 39, 11, 15-16.
} 
superior network of fulfillment centers. ${ }^{74}$ Finally, Apple's initial control over high-end smartphones, and the app ecosystem associated with them, appears to be due to the company's innovation of the smartphone. ${ }^{75}$ As such, the core of these firms' control over inputs is immune to antitrust scrutiny. However, Google and Facebook have also grown through the acquisition of nascent competitors, particularly Facebook, which acquired Instagram and WhatsApp at crucial moments in its development. ${ }^{76}$ It is unlikely, however, that these acquisitions violate the merger rules, because search and social media services both improve as the number of users increases, and the companies' acquisitions served to increase usage of these companies' services. ${ }^{77}$

\section{THE EXERCISE OF POWER}

The problem of the acquisition of power is the least controversial and best understood part of antitrust, which may explain why it has remained the most robust area of antitrust enforcement in recent decades. ${ }^{78}$ By contrast, the problem of how to regulate the exercise of power is a source of widespread misunderstanding. Perhaps for this reason it is also the area in which enforcement has been at an ebb in recent decades.

\section{A. Theory}

\section{Maximizing Profits Consistent with Willingness to Pay}

However a firm has acquired control over an input, once the firm has control the firm will use it to dictate terms to buyers, and buyers will

\footnotetext{
${ }^{74}$ See Jean-François Houde et al., Economies of Density in E-Commerce: A Study of Amazon's Fulfillment Center Network, No. ID 2961085, 38 (2017); Podcasts et al., How Amazon Delivers on Its Core Product: Convenience, KNOWLEDGE@WHARTON, https://knowledge.wharton.upenn.edu/article/power-amazons-fulfillment-network/ (last visited Feb. 13, 2021).

${ }^{75}$ See Joel West \& Michael Mace, Browsing as the Killer App: Explaining the Rapid Success of Apple's IPhone, 34 TELECOMMUNICATIONS POLICY 270, 277-84 (2010).

${ }^{76}$ See Subcommittee on Antitrust, Commercial, and Administrative Law of the Committee on the Judiciary of the United States House of Representatives, supra note 72, at 150-63, 175.

${ }^{77}$ See Fiona Scott Morton et al., Stigler Committee on Digital Platforms: Final Report 2019, 34-40; Ramsi Woodcock, Google and Shifting Conceptions of What It Means to Improve a Product, TRUTH ON THE MARKET, https://truthonthemarket.com/2020/12/16/google-andshifting-conceptions-of-what-it-means-to-improve-a-product/ (last visited Feb. 13, 2021).

${ }^{78}$ See Jonathan B. Baker, Exclusion as a Core Competition Concern, 78 ANTITRUST LJ 527, 528-29 (2012).
} 
acquiesce because the firm can refuse to supply the input to those who do not accept the terms and there is nowhere else to go to get the input. The first and most obvious term that the firm will impose is a price term: if you want access, pay me more. In most jurisdictions, this in itself can constitute a violation of antitrust rules against the exercise of power. ${ }^{79}$ But in the United States the law developed differently. Here, the antitrust laws do not, ever, prohibit the use of power to charge high prices for the direct purpose of extracting profits, although, as we shall see, the antitrust laws do prohibit the use of discriminatory pricing to favor some downstream competitors over others. ${ }^{80}$

Instead, the problem of excessive pricing is left to Congress to solve by creating sector-specific price regulation regimes. ${ }^{81}$ So, for example, Congress responded to the growth of telephone monopolies a century ago by giving the Interstate Commerce Commission, and eventually the Federal Communications Commission, the power to regulate telephone rates. ${ }^{82}$ This peculiar division of labor in American antitrust is not a result of latent American conservatism with respect to economic regulation, however, but instead a consequence of progressive enthusiasm for rate regulation a century ago, combined with distrust of the willingness of courts, which progressives saw as unbearably conservative, to implement rate regulation. ${ }^{83}$ Indeed, the courts fought the creation of the first rate regulatory agencies on constitutional grounds for half a century, and progressives saw antitrust's refusal to dabble in prices as a sign of respect for the price regulation enterprise carried out by administrative agencies and a bulwark against conservative interference with them. ${ }^{84}$ There was a time in the mid-20 century when $25 \%$ of the US economy by GDP was price regulated, but the deregulatory movement has reduced that percent to near-zero today. ${ }^{85}$

\footnotetext{
79 See, e.g., Thomas Ackermann, Excessive Pricing and the Goals of Competition Law, in THE GoALs OF COMPETITION LAW 349, 354-57 (Daniel Zimmer ed., 2012).

${ }^{80}$ See HovenKAMP, supra note 8, at 356-58, 387-88, 739. For the argument that antitrust law should embrace an excessive pricing rule, see Ramsi A. Woodcock, The Antitrust Duty to Charge Low Prices, 39 CARdozo L. REV. 1741 (2018); Ramsi A. Woodcock, The Antitrust Case for Consumer Primacy in Corporate Governance, 10 UC IRVINE L. REV. (2020).

${ }^{81}$ See HovenKAMP, supra note 8 , at 387-88.

${ }^{82}$ See RiCHARD H. K VIETOR, CONTRIVED COMPETITION: REGULATION AND DEREGULATION IN AMERICA 170-71 (1996); RICHARD R JOHN, NETWORK NATION: INVENTING AMERICAN TELECOMMUNICATIONS 343-44 (2015).

${ }^{83}$ See BARBARA FrIED, The Progressive Assault on LAISSEZ FAIRE: Robert HALE AND THE FIRST LAW AND ECONOMICS MOVEMENT 161-65 (1998); Herbert Hovenkamp, Antitrust and the "Filed Rate" Doctrine: Deregulation and State Action, No. ID 2191566, 1-2 (2012).

${ }^{84}$ See FRIED, supra note 83, at 161-65; Hovenkamp, supra note 83, at 1-2.

${ }^{85}$ See VIETOR, supra note 82, at 16; Ackermann, supra note 79, at 352.
} 
Antitrust has not, however, adjusted to fill the gap in price regulation that has created, and so today the charging of high prices with a view to extracting as much profit as possible given willingness to pay remains a peculiar blind spot in policy. ${ }^{86}$ That is a shame, because extraction of the maximum of profits consistent with willingness to pay is the main way in which powerful firms oppress buyers, and so even after antitrust has prohibited all other exercises of power, oppression will remain. ${ }^{87}$

\section{Expanding Willingness to Pay}

An input controller can also exercise power not for the purpose of extracting the maximum profits that buyers are willing to pay but for increasing that maximum. There are four main ways to increase the maximum. The first is to improve the quality of the input that the firm sells. ${ }^{88}$ This does not really count as an exercise of power so much as the creation of additional power through product improvement - the making of a new, even more essential, input - and so is regulated only by the rules governing the acquisition of power, which categorically permit such product-improving activity. ${ }^{89}$ The second is to improve not the quality of the input but the quality of the downstream product that is sold to end consumers. This increases the willingness of end consumers to pay, which in turn increases the profits that downstream firms can extract from consumers, which in turn increases the profits that the input controller can extract from the downstream firms. ${ }^{90}$ Improving downstream products requires an exercise of power because the input controller must dictate changes to the way downstream firms produce their products in order to improve the quality of the product that reaches end consumers. We shall see that product-improving conduct of this kind is also categorically legal.

The remaining two methods do not increase the absolute maximum that buyers are willing to pay so much as they increase the ability of the input controller to get at that maximum through the charging of higher prices. Defects in the bargaining process, such as the stubborn refusal of a buyer to agree to a price that the buyer is willing to pay in principle, or a failure on

\footnotetext{
${ }^{86}$ See Woodcock, The Antitrust Duty to Charge Low Prices, supra note 80, at 1755-60; Woodcock, The Contrasting Approaches to Power of the Modern State and the Antitrust Laws: Lessons for Platform Regulation, supra note 5.

87 See Woodcock, The Contrasting Approaches to Power of the Modern State and the Antitrust Laws: Lessons for Platform Regulation, supra note 5.

${ }^{88}$ See Scherer, supra note 66, at 563-64.

${ }^{89}$ See DANIEl J GIFFORD \& Robert T KudRle, The ATLANTIC Divide IN ANTITRUST AN EXAMINATION OF US AND EU COMPETITION POLICY 28 (2015).

${ }^{90}$ See HoVENKAMP, supra note 8, at 544.
} 
the part of the buyer to negotiate better terms with downstream consumers, which in turn leaves the buyer unable to pay input prices that in principle the buyer ought to be able to pay, can prevent an input controller from charging the highest possible prices for the input. ${ }^{91}$ The input controller can achieve pricing consistent with the true maximum that buyers should be willing to pay by exercising power over downstream firms: punishing those that fail to pony up by depriving them of supply. ${ }^{92}$ Finally, the input controller can extract more profits from buyers by learning more about them, in order better to identify the maximum they are willing to pay and raising prices accordingly. ${ }^{93}$ This too involves an exercise of power because the firm gathers intelligence by demanding of downstream firms that information be passed up to it. These two forms of extracting more profits from buyers are illegal unless combined in some necessary fashion with product-improving conduct. ${ }^{94}$

3. The Role of Discrimination in the Supply of Inputs in Expanding Willingness to Pay

The means an input controller uses to exercise power to improve downstream products, discipline downstream buyers, or extract information from them is discrimination in the supply of inputs to downstream firms that brings about a disparate impact on their fortunes. This is perhaps clearest when the input controller discriminates in the prices that the controller charges downstream firms for its inputs. In this case, the firm uses discounts to favor downstream producers that make better products, readily agree to the input controller's terms, or supply more accurate information on willingness to pay, and to disfavor those downstream producers that do not, putting them at a competitive disadvantage and driving them from the market if they do not correct their behavior.

This use of price discrimination to increase willingness to pay contrasts rather starkly with another kind of price discrimination, which is aimed at extracting the greatest possible profits from buyers while taking their

\footnotetext{
${ }^{91}$ See Robert Cooter, The Cost of Coase, 11 J. LEGAL STUD. 1, 15-20 (1982).

${ }^{92}$ Einer Elhauge helpfully collects the many ways in which an input controller can seek to increase effective willingness to pay without improving the product in his treatment of tying. See Einer Elhauge, Tying, Bundled Discounts, and the Death of the Single Monopoly Profit Theory, 123 HARV. L. REV. 397 (2009). One of the contributions of the present Article is the Article's recognition that because tying is of the same basic structure as all exercises of power, Elhauge's list applies to all exercises of power generally and not just to tying. See infra Section IV.B.4. The fourth and fifth examples in Elhauge's list are examples of the punishment of downstream firms described here. See id. at 413-19.

${ }^{93}$ See Elhauge, supra note 92, at 403-13.

${ }^{94}$ See infra Part IV.B.
} 
willingness to pay, as modified by their stubbornness and the amount of information the input controller has about them, as given and fixed. To extract the maximum profit from firms given fixed willingness to pay, the input controller may price discriminate by charging different prices to different buyers. ${ }^{95}$ But this is not the sort of disparate-impact-producing discrimination created by attempts to increase willingness to pay, because if implemented properly it should leave all buyers in the same position: with no profits of their own at all, for the maximum will have been extracted from each. ${ }^{96}$ The prices charged to each buyer will be different, for each may have different costs and so different levels of profitability in its own dealings downstream with end consumers, but the effect will be to leave each with a zero profit on its own sales to end consumers. ${ }^{97}$

By contrast, the input controller who seeks to expand willingness to pay in any of the three ways described above, rather than to set price to ensure that all buyers can afford to buy (albeit at the maximum possible prices), will set prices that disfavored firms cannot afford, intentionally forgoing the opportunity to profit from them in order to increase the willingness of the others to pay by a greater amount. Discrimination does not need to be secured through prices: an input controller can just as easily use the threat not to sell to a disfavored firm in order to impose its will on downstream markets and thereby increase willingness to pay. But however the input controller does impose its will, the modus operandi is necessarily that of discrimination. ${ }^{98}$

a. Discrimination and Product Improvement

A classic example of discriminatory conduct in aid of product improvement is vertical integration downstream by the input controller combined with a refusal to sell to downstream competitors on the same terms at which the input controller supplies to itself. ${ }^{99}$ In this case the input

\footnotetext{
95 Technically, the firm should charge prices designed to earn varying rates of return from each buyer on each unit sold. See Ramsi A. Woodcock, Personalized Pricing as Monopolization, 51 ConN. L. REV. 311, 313 n.1 (2019).

96 That is, price discrimination ideally operates inframarginally, and so has no affect on competition, which is why perfect price discrimination is held to be efficient. See Hal R. Varian, Price Discrimination, in HANDBOOK OF INDUSTRIAL ORGANIZATION 597, 601 (1989).

${ }^{97}$ See id. at 600.

${ }^{98}$ Antitrust has never fully appreciated the key role played by discrimination in exercises of power aimed at increasing willingness to pay. The Robinson-Patman Act seems to touch on it, however, in prohibiting price discrimination by manufacturers against retailers but not price discrimination against end consumers, which latter can only be aimed at extracting profits rather than at increasing willingness to pay. See HoVENKAMP, supra note 8, at 739. ${ }^{99}$ See id. at 382-87.
} 
controller improves the product by incorporating its input into the downstream production process on its own instead of selling the input to a downstream firm to carry out that process. ${ }^{100}$ The firm's refusal to supply the input to downstream competitors on equal terms ensures that the input controller's product improvement is distributed to as many end consumers as possible, maximizing the number of consumers for which willingness to pay increases. But an input controller does not always need to undertake downstream production itself in order to increase the quality of the product. Cutting off underperforming firms, so as to induce the rest to improve, may be enough. ${ }^{101}$ Indeed, the firm may make the improvements it wishes downstream firms to undertake explicit by requiring every purchaser of its inputs to sign a contract promising to adhere to certain production standards. ${ }^{102}$ This may not appear discriminatory on its face, but it will necessarily have a disparate impact because no two firms are the same: some will find it easier to comply than others, and those that find it harder to comply will suffer. ${ }^{103}$

\section{b. Discrimination and the Disciplining of Buyers}

Discrimination aimed at disciplining downstream buyers takes many forms. In one common scenario, an input controller sees that a downstream firm will use revenues or know-how that the firm generates from its downstream operations eventually to enter the upstream input market, challenging the input controller. ${ }^{104}$ That will increase the profits of the downstream firm, and so must increase the downstream firm's willingness to pay for the input, which after all is key to enabling the downstream firm eventually to move upstream. The input controller might therefore demand a higher price for the input, so as to extract those additional future profits, but the downstream firm might refuse to pay, perhaps because the firm does not hold the same view as the upstream firm regarding whether it will be able to move into the input market. ${ }^{105}$ Or the downstream firm may lack the cash or

100 A hallmark of Chicago School thinking associated with the "single monopoly profit" theory is the view that the only possible rationale for discriminatory conduct is the improvement of the downstream product. See Elhauge, supra note 92, at 404.

${ }^{101}$ Antitrust is most familiar with this behavior in the context of nonprice intrabrand vertical restraints: a manufacturer cutting off an underperforming retailer, for example. See, e.g., Continental TV, Inc. v. GTE Sylvania Inc., 433 U.S. 36, 39-40 (1977).

102 See Bernstein, supra note 67, at 566-72.

${ }^{103}$ I mean by "disparate impact" intentionally to evoke the concept in discrimination law. See MiCHAEL J ZIMMER ET AL., CASES AND MATERIALS ON EMPLOYMENT DiSCRIMINATION 321-425 (6th ed. 2003).

${ }^{104}$ See Elhauge, supra note 92, at 417-19 (discussing nascent competitor arguments).

105 Similarly, it has been argued that "asymmetric expectations" can prevent firms from 
credit needed to pay out what are in effect future profits and the parties may be unable to negotiate a contract that would bind the firm to future payment of those profits. Whatever the case, the input controller may cut the downstream firm off from the input, or otherwise discriminate in input supply to the downstream firm, as punishment for failing to agree to terms, or indeed may drive the downstream firm from the market entirely so as to retain its future profits in the most secure fashion possible, which is to continue to earn them itself without challenge from a nascent competitor clawing its way up from the downstream market.

In another common scenario, a downstream firm does not see itself as benefitting from the input supplied by the input controller even though the downstream firm really does benefit from it. ${ }^{106}$ A restaurant that caters mostly to locals might not, for example, understand itself to benefit from proximity to a hotel even though the business the restaurant receives from hotel guests is actually crucial in allowing the restaurant to cover its month costs. ${ }^{107}$ If the hotel were to send the restaurant a bill designed to extract all of the profits from this restaurant in exchange for provision of this essential proximity input, the restaurant would likely balk. The input controller can respond by cutting off access to the input or otherwise discriminating in its supply to the downstream firm until either the downstream firm pays the bill or is driven from the market and only firms that agree to pay the bill—which might include firms run by the input controller itself-remain in the market. ${ }^{108}$ The hotel can steer guests away from the restaurant that refuses to pay the bill and toward those that do pay, or to the hotel's own restaurant, by for example creating a vacation package that includes meals in some restaurants but not in others. ${ }^{109}$

Textbooks are another example. The Internet created a vast used textbook market that, in principle, should have no effect on publisher profits because publishers control an essential input into the used textbook market: the supply of new books. ${ }^{110}$ Thus in principle they should be able to bill used book sellers for any lost profits. The used book sellers would then pass the fees on to students, who would pay them because their only alternative is to pay full price for new books. In practice, however, used book sellers do not pay such fees, and do not appear even to have been asked to do so. Instead,

settling patent disputes. See Robert D. Willig \& John P. Bigelow, Antitrust Policy Toward Agreements That Settle Patent Litigation, 49 ANTITRUST BULl. 655, 692-93 (2004).

106 See Elhauge, supra note 92, at 413-17.

107 See GAVIL ET AL., supra note 18, at 962-63.

108 See id.

${ }^{109}$ See id.

110 See Consolidated Amended Class Action Complaint at 2, In re Inclusive Access Course Materials Antitrust Litigation, No. 20 MDL No. 2946 (District Court 2020). 
the publishers have embarked on a campaign to alter the nature of the input they supply in a way that is facially neutral but which will have a disparate impact on used book sellers: they are shifting away from the sale of print textbooks, which can be resold, to online-only textbooks, which cannot be resold. ${ }^{111}$ In this way, the publishers' discriminatory conduct allows them to capture the profits that used book sellers should be willing to pay but refuse to pay.

\section{c. Discrimination in Aid of Information Acquisition}

Discrimination in aid of information acquisition may be undertaken through vertical integration (i.e., producing and selling in the downstream market, in addition to the input market) combined with a refusal to supply to competitors in the downstream market on non-discriminatory terms. ${ }^{112}$ The input controller enters the downstream market in an attempt to do a better job than incumbents at measuring the willingness of end consumers to pay, or to circumvent attempts by downstream firms to hide their profits from the input controller. The refusal to supply to downstream competitors ensures that they will wither and as many end consumers as possible will do business with the input controller and in so doing reveal their willingness to pay.

Perhaps the most famous example of discrimination in aid of information acquisition is the variable proportions tie. ${ }^{113}$ If the final product consists of the input plus some additional component produced by downstream firms, one that consumers combine with the input in amounts that may differ from consumer to consumer based on taste, as students may use a greater or a lesser number of pencils along with their erasers, then the amount of the downstream good purchased may proxy for willingness to pay-rich kids buy more pencils - and so the input controller can identify willingness to pay and raise price accordingly by varying the price of the downstream good. ${ }^{114}$

Vertical integration facilitates this, but is not necessary, any more than vertical integration is necessary to product improvement or the disciplining of buyers. The input controller might also simply dictate, as part of the terms of sale of the input, that downstream firms pay a royalty per unit of the downstream good sold, which royalty would then be passed on to end consumers through price increases. This approach would not, however, be any less discriminatory, for it would have a disparate impact on downstream firms, harming those that produce with higher costs by making their products

\footnotetext{
${ }^{111}$ See id. at 4-5.

112 See Elhauge, supra note 92, at 403-13.

${ }_{113}$ See id. at 404-5.

${ }^{114}$ See id.
} 
unaffordable to end consumers.

4. Whether to Permit Discrimination as a Choice between Letting the Input Controller Decide How to Make the End Product and Letting End Consumers Decide How to Make the End Product

Discrimination in the supply of inputs interests antitrust because it is made possible by centralization of input control: the absence of competition at the input level. It is an exercise of power. But newcomers to antitrust and casual observers more generally often mistakenly believe that discrimination in the supply of inputs is of interest because it harms downstream competition, favoring some firms-often those owned by the input controller - and disfavoring others, thereby biasing the competitive playing field. ${ }^{115}$ This harm to competition seems starkest when an input controller refuses to supply to a downstream firm that competes directly with the controller's own downstream operations. In recent years, this has led to calls for a general rule against competing on your own platform, where "platform" means "input" and firms that supply downstream operations in which they themselves have an ownership stake are said to compete on their own platforms. ${ }^{116}$ The rule seems necessary to prevent the inherent conflict of interest that an input supplier has in supplying markets in which the supplier itself competes. ${ }^{117}$ It therefore comes as a surprise to newcomers and casual observers that antitrust does not ban discrimination in supply as such, or even refusals to deal with downstream competitors, at least not as a general matter. ${ }^{118}$ The gap in the law seems so obviously at odds with antitrust's mission to protect competition that it reeks of capture by corporate forces. ${ }^{119}$

The truth is more subtle and interesting: all production involves

115 See Team Warren, Here's How We Can Break up Big Tech, TEAM WARREN (Mar. 8, 2019), https://medium.com/@teamwarren/heres-how-we-can-break-up-big-tech$9 \mathrm{ad} 9 \mathrm{e} 0 \mathrm{da} 324 \mathrm{c}$.

116 See, e.g., id.; Subcommittee on Antitrust, Commercial, and Administrative Law of the Committee on the Judiciary of the United States House of Representatives, supra note 72, at 397.

117 See Subcommittee on Antitrust, Commercial, and Administrative Law of the Committee on the Judiciary of the United States House of Representatives, supra note 72, at 16 ("Amazon's dual role as an operator of its marketplace that hosts third-party sellers, and a seller in that same marketplace, creates an inherent conflict of interest. This conflict incentivizes Amazon to exploit its access to competing sellers' data and information, among other anticompetitive conduct.").

118 See Woodcock, supra note 20, at 116-20, 165-66 (objecting to the absence of such a blanket rule).

119 See Ramsi A. Woodcock, Digital Monopoly without Regret, CONCURRENCES, 2020, at $53,53-54$. 
discrimination, and indeed denial of inputs to downstream competitors. As a result, the apparently competition-harmful conduct that is input discrimination is no more objectionable in principle than the act of production itself - no worse than making a pencil, say - and of interest to antitrust not because of its effects on competition in the downstream market, but because it involves an exercise of power based on the prior demise of competition at the input level. ${ }^{120}$

To see why all production is a denial of inputs to a downstream competitor, it is necessary to consider the form that an entirely nondiscriminatory production process would take. Once that is properly understood, the impossibility of producing anything entirely through that process, and the consequent necessity of undermining competition through input denial in order to produce anything, will become clear. Every product is an assemblage of components of arbitrarily large number, depending on how finely a component is defined: if a molecule is a component, then a cube of sugar contains a very large number of components indeed. ${ }^{121} \mathrm{~A}$ truly nondiscriminatory production process is one in which any producer can compete on equal terms to supply any component of the product. As a result, in such a process the components are brought together in a linear supply chain, in which the makers of one component-it can be any-sell that component downstream to the makers of the next, which combine the component they produce with the first and sell the resulting bundle downstream to the maker of the next component, which combines that component with the bundle and sells that along in turn until at the end of the chain the maker of the last remaining component adds it in to the nowswollen bundle to complete the product and then sells the completed product to end consumers. At each step in the chain the sellers must supply the partially completed product-the bundle - to the next level on nondiscriminatory terms, allowing any firm that wishes to compete to sell any component to participate in the market to sell that component on a level playing field.

All products are differentiated, if only in time and place of sale, or in brand name, each of which is a characteristic that matters to buyers, and so at each level of the supply chain a firm faces the choice which kind of bundle of components to combine with its own and sell along down the chain, and end consumers face a set of choices between products that have a level of variation that is related to the fineness with which components are defined

\footnotetext{
${ }^{120}$ See Woodcock, supra note 20, at 138 n. 80.

$1217.0459 \times 10^{21}$ molecules, to be precise. See 3.09c Moles of Sucrose within a Sugar Cube - Week 3, COURSERA, https://www.coursera.org/lecture/chemistry-1/3-09c-moles-ofsucrose-within-a-sugar-cube-sxBVT (last visited Feb. 23, 2021).
} 
and therefore to the number of levels of the supply chain. ${ }^{122}$ Consider, for example, a chain with three levels, the first of which is controlled by a single input controller producing a single version of the input, the second of which contains two competitors each producing a single, but differentiated, version of the component associated with that level, and the third of which contains four competitors, each producing a single, but differentiated, version of the component associated with that level. Figure 2 gives a tree diagram showing the four possible ways in which the components produced in this supply chain might be combined to produce the finished product.

Since there are only two firms operating at the final level, and each sells a different product, we must have two different paths through the tree, each ending in a different third component. In the example that is bolded in the figure, consumers are able to choose between products that include completely different approaches to two of the components: one has the first version of the second component and the second version of the third and the other has the second version of the second and the first version of the third. This is possible only because the supply chain has been defined to include the second and third components, instead of treating the second component, for example, as part of the first, and because competition in the supply of each of the second and the third components means that alternative flavors of each are available and may be combined in different ways depending on the purchase choices made by the makers of the third component.

If, by contrast, the second component were considered part of the first, then our controller of the first input, who produces only one kind of input, might choose to include the first flavor of the second input in the input the input controller sells and so it would become impossible to purchase a final product that contains the second flavor of the second component. Similarly, if there were only one maker of the second component-perhaps because the input controller had refused to sell the first component to more than one maker of the second component - then it would be impossible to purchase a final product that contains the second flavor of the second component. It follows that as one adds components, and therefore levels of the supply chain, and as one adds competitors at each level, the possible variety of end

${ }^{122}$ See CHAMBERLIN, supra note 29, at 71-73. 
products sold to consumers increases.

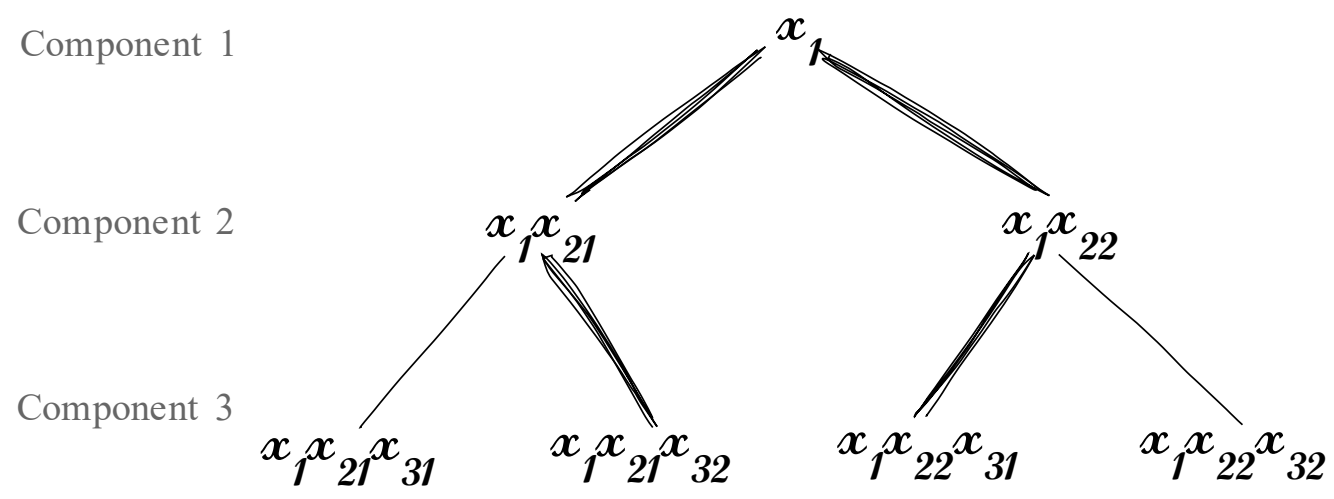

Figure 2

Figure 2 is drawn to show that the component that stands at the head of the supply chain is under the complete control of a single firm. When a component falls under the control of a single firm, nondiscrimination in the supply of inputs can be guaranteed only by fiat: the controller of the input has the power to discriminate in the sale of the input, and may choose to do so. ${ }^{123}$ But if there is no controller of any component, then in principle nondiscrimination might be the natural outcome of competitive forces at each level of the supply chain. Any attempt by a seller to discriminate would be frustrated by the willingness of competing sellers to supply to disfavored firms on nondiscriminatory terms and so to increase business. ${ }^{124}$ The less differentiated the products sold in the market, and the more uniform competitors' costs of production, the more likely would it be that competition would prevent discrimination. ${ }^{125}$

Whether the result of competition or regulation, a supply chain in which each component of the finished product is sold on nondiscriminatory terms is one in which end consumers decide how the product is made. ${ }^{126}$ End consumers choose between the combinations of components offered to them in the market-between the bundle with the first flavor of the second

\footnotetext{
${ }^{123} C f$. W. Kip ViscUSi ET AL., ECONOMICS OF REGULATION AND ANTITRUST 438-41 (5th ed. 2018) (discussing the regulation of natural monopoly).

124 Cf. Ross Levine et al., Racial Discrimination and Competition, SocIAL SCIENCE RESEARCH NETWORK 32, https://papers.ssrn.com/abstract=1447374 (last visited Feb. 24, 2021); GARY S BECKER, THE ECONOMICS OF DiSCRIMINATION. (2010).

125 See CHAMBERLIN, supra note 29, at 71-73.

${ }^{126} C f$. Neil W. Averitt \& Robert H. Lande, Consumer Sovereignty: A Unified Theory of Antitrust and Consumer Protection Law, 65 ANTITRUST L.J. 713, 715-16 (1997).
} 
component and the second flavor of the third or the second flavor of the second and the first flavor of the third in Figure 2-and in so doing drive profits to the firm that sells the bundle they prefer and away from the firm that sells the bundle they dislike. ${ }^{127}$ These preferences are in turn transmitted up the supply chain, driving sales in upstream component markets. Firms will experiment with the inputs they buy until firms can offer consumers an end product with the combination of components that consumers most prefer. ${ }^{128}$ In Figure 2, the bolded supply lines will wander across the tree of possibilities until the lines most preferred by consumers are reached. If consumer preferences are uniform enough, there may be only one optimal product and sellers of all other options will be driven from the market and eventually only a single route through the production tree will remain: the one that combines components in the way consumers prefer.

This is only possible, however, if at each level of the supply chain there is nondiscrimination in the sale of components, which allows firms to make their input purchase decisions based exclusively on the profit signals being transmitted up to them from consumers, rather than based on input price signals being sent by sellers that go beyond the transmittal of production costs or prices designed to extract profits and are instead designed to influence which firms get the seller's inputs - that is, to discriminate in a manner that causes a disparate impact. ${ }^{129}$ If, instead, there is an input controller in the supply chain, and the rule of nondiscrimination in input supply is not guaranteed, then the controller can counteract the wishes of end consumers by denying some downstream firms access to the components they prefer, and which, by extension, end consumers prefer those downstream firms to have. ${ }^{130}$ The seller in Figure 2 chooses not to sell to the maker of the second flavor of the second component, and so, even if consumers clamber for an end product that includes the second flavor of the second component, they cannot have it.

Stated in this way, it seems obvious that there should never be any discrimination in the sale of inputs. ${ }^{131}$ But that rests on the faulty assumption that end consumers - or buyers anywhere in the supply chain-actually know which collection of components is best. ${ }^{132}$ For in order for consumers

\footnotetext{
127 See Abba P. Lerner, The Economics and Politics of Consumer Sovereignty, 62 AM. ECON. REV. 258, 261 (1972) ("[The market guides production to what is preferred by consumers[.]").

${ }^{128}$ See id.

${ }^{129}$ Cf. id.

130 See Averitt \& Lande, supra note 126, at 718-19.

${ }^{131}$ Cf. Subcommittee on Antitrust, Commercial, and Administrative Law of the Committee on the Judiciary of the United States House of Representatives, supra note 72, at 16.

${ }^{132} \mathrm{Cf}$. Lerner, supra note 127, at 258.
} 
to choose the product that has the most desirable set of components, that product must be offered to them, and in order for it to be offered to them, firms at each level of the supply chain must think to purchase components in a manner that leads to production of that particular product. ${ }^{133}$ And while it is true that the willingness of consumers to pay for the best products creates an incentive for firms to make and sell the best products, it does not follow magically from the existence of such an incentive that the supply chain will act in accordance with it, any more than the fact that an incentive to industrialize existed throughout the first 310,000 years of human history magically induced humans to industrialize at any point in that span of time until they in fact did start to industrialize about 10,000 years ago. ${ }^{134}$ If consumers in our running example really do prefer a product made with the second flavor of the second component and the second flavor of the third, that product will in fact be produced only if the maker of the second flavor of the third product has the brilliant idea to try buying its inputs from the maker of the second flavor of the second input, rather than, as drawn in the figure, buying them from the maker of the first flavor of the second component.

Where buyers fail to make the right decisions, a seller that controls an input and therefore has the power to discriminate among buyers and so to choose the right combination of components, might succeed. ${ }^{135}$ The seller of the second flavor of the second component might know better than the seller of the second flavor of the third component that their two components belong together in the finished product, and if the seller of the second flavor of the second component knew that and had the power to discriminate (not pictured in Figure 2, for in that figure the sellers of the second component compete), then it would be better for end consumers were that seller to discriminate. It follows that the basic question whether firms should be permitted to discriminate in the sale of inputs is really the question whether sellers should be permitted to decide the best set of components to bring together to form a product or whether end consumers should make that decision.

When discrimination is permitted and sellers decide, it is the seller with the most centralized control over a given component that has ultimate decision-making power. ${ }^{136}$ This seller occupies a bottleneck in the tree and

\footnotetext{
133 See Lon L. Fuller, Some Reflections on Legal and Economic Freedoms--A Review of Robert L. Hale's Freedom through Law, 54 COLUM. L. REV. 70, 72 (1954) (discussing the freedom not to choose).

134 See Ramsi A. Woodcock, The Market as a Learning Algorithm: Consequences for Regulation and Antitrust, No. 3661971, https://ssrn.com/abstract=3661971.

${ }^{135}$ See Fuller, supra note 133, at 72.

136 See Aaron Director \& Edward H. Levi, Law and the Future: Trade Regulation, 51 Nw. U. L. REV. 281, 290 (1956).
} 
can dictate terms of sale downstream. ${ }^{137}$ These terms can discriminate not only in immediate buyers of the input controller's product but also in any downstream buyers however far removed down the supply chain, for the seller can simply stipulate the terms according to which the buyer sells downstream to other buyers. Similarly, if the input controller happens to be located at an intermediate point in the supply chain, the controller can decide not only which inputs the controller buys - free of any discrimination from sellers, since the input controller has the power in the supply chain-but also which inputs sellers themselves acquire, by stipulating the terms according to which the sellers buy upstream from other sellers. ${ }^{138}$ Thus the input controller can dictate terms both downstream and upstream, and so for purposes of analytic clarity, the input controller can always be placed at the very top of the linear supply chain, to emphasize the controller's ability to dictate terms to the entire chain. Figure 2 reflects this choice. Thus the problem of discrimination is the problem whether to permit the most powerful firm in the supply chain to pick the best way to produce the end product or, by prohibiting discrimination, to permit end consumers to decide the best way to produce the end product. (A third option is to break up control over the input, which then would eliminate the ability of any firm to discriminate in the supply of inputs. That was the subject of the discussion in Part III on the acquisition of power. However, as will become clear momentarily, breakup is always a matter of degree. There must be power in any supply chain in order for production to take place.)

\section{A Product Is Defined by the Ambit of an Input Controller's Discrimination}

When an input controller in a supply chain exercises power fully to determine the components used in the final product sold to consumers, the end product is produced by the input controller in the sense that the controller has directed the making of the end product with respect to all of its components. In general, we tend to make the mistake of assuming instead that whatever a firm sells is its product, and under that definition the product is made by the firm that does business with the end consumer, rather than by the input controller. ${ }^{139}$ But it is peculiar to suppose that a firm that is entirely

\footnotetext{
137 See id.

138 This is starkly illustrated by the terms imposed by large manufacturers like John Deere on their suppliers. See Bernstein, supra note 67, at 566-72.

139 Thus even Oliver Williamson, a very careful student of vertical integration indeed, takes it for granted that vertical integration means the acquisition of a supplier, without any attention to the question whether that supplier was already effectively under the control of the firm, due to the firm's control over its own input category, and therefore already
} 
under the thumb of the input controller, a beneficiary of the controller's discrimination but implicitly also a victim because of the implicit threat of punishment for failing to comply with the controller's wishes, would be the maker of the product sold to consumers. ${ }^{140}$

It follows that if the input controller chooses not to engage in discrimination with respect to the sale of any component within the supply chain, that component and all those downstream from it are no longer a part of the input controller's product. ${ }^{141}$ There must be at least one new product for each of the firms that purchases in a nondiscriminatory fashion from the input controller, for each such firm now stands at the head of a new component tree and, in virtue of being the only firm to sell its particular flavor of the component, controls a bottleneck with respect to that tree. ${ }^{142}$ The extent of the power created by the bottleneck is limited so long as there is more than one firm that buys in nondiscriminatory fashion from the input controller, and so downstream component makers can substitute a different

effectively integrated, regardless whether the supplier remained formally separate as a legal matter (i.e., not owned by the firm) or happened to produce a physically separate output from the one produced by the firm. See Oliver E. WILliAMSON, THE ECONOMIC INSTITUTIONS OF CAPitalism: Firms, Markets, Relational Contracting 135-37 (1985). Indeed, Williamson's definition of the limit of the firm appears to be the extent of the assets to which the firm has title. See id. (trying to answer the question why firms are not larger by considering what would happen if a firm were to acquire its supplier). Similarly, he appears at times to consider the "make" in the "make or buy" decision to turn on whether a supplier is to be acquired or not, quite regardless the level of control the firm exercises over the supplier even when the firm does not own the supplier. See id. at 196-97. At other times, he seems to view physical or technological separability, rather than control, as distinguishing products or perhaps firms. See id. at 96 (stating that "every separable stage of production" is "one for which a careful assessment of make-or-buy is warranted"). Other examples of this mistaken tendency to assume that the formal legal limits of the firm (i.e., the extent of the assets to which the firm has title) coincide with the ambit of its actual control over resources, such that when one firm acquires another something meaningful has happened - control has actually changed hands - abound and indeed serve as the foundation for antitrust's traditional conception of the limits of the firm and the significance of vertical merger. See SCHERER \& Ross, supra note 60, at 190; 15 U.S.C. $§ 18$ (2018) (defining antitrust-relevant mergers as involving the acquisition of the stock or assets of another firm). Ronald Coase seems to come closer to the mark in identifying the firm with control, although he does not seem to consider the question whether a firm can control without owning. See R. H. Coase, The Nature of the Firm, 4 ECONOMICA 386, 387-90 (1937).

${ }^{140}$ Cf. WiLliamSON, supra note 139, at 53-54 (treating the vertical "lock-in" associated with the supply of "transaction-specific assets" as something that tends to lead to vertical integration through purchase rather than as constituting effective vertical integration itself regardless of the formal legal relationship between supplier and firm).

${ }^{141}$ Cf. id.

142 See CHAMBERLIN, supra note 29, at 71-73. 
supplier if the terms imposed by one are too harsh. ${ }^{143}$ If this power limitation is not too great, however, it may be possible for each firm to discriminate in the way it supplies to firms further downstream, and that will bring downstream components within the ambit of the product sold by each firm. ${ }^{144}$ So, for example, in Figure 2, if the input controller chooses to sell in nondiscriminatory fashion to makers of the first component, then at least two new products are born, one that has the first flavor of the second component and one that has the second flavor of the second component. If the first flavor of the second component is viewed as essential by makers of the third component, then the maker of the first flavor of the second component will be able to discriminate in supplying them, because there will be no competition from the maker of the second flavor of the second component, and so the product sold by the maker of the first flavor of the second component will include the third component as well, as indicated by the dashed box in Figure 3. If not, however, then makers of the third component, which will be able to purchase second components without being subject to discrimination, will all themselves produce products that are separate from those produced by the makers of the second components or by the maker of the first.

\footnotetext{
143 See id. at 65-68.

${ }^{144}$ In a sense, a firm always has some power to discriminate, because, as will be discussed shortly, every product can be broken down into components, and these can be further broken down into subcomponents, and so on, ad infinitum. Thus the firm that appears powerless because it sells a standardized product — ball bearings, for example — and can hardly refuse to sell to some buyers because it wants its bearings to go into certain machines, but not others, without going bankrupt for lack of business, nevertheless does control an entire supply chain associated with the production of those ball bearings itself. The firm decides which, out of a range of possible suppliers, should supply the metal to be used in the particular bearings that the firm produces, which, out of a range of possible machinery companies, should supply the machinery used to form the bearings, and so on. While, as discussed below, we generally think of these as supply choices, they can be reconceptualized as choices by the ball bearing manufacturer regarding to which companies in a linear supply chain consisting of metal suppliers and machinery suppliers to supply its own bearing-making know-how in order to achieve a ball bearing end product. To the extent that the ball bearing maker is able to choose which firm supplies metal and which machinery, rather than feeling compelled to supply the firm's know-how to any metals supplier and any machinery maker that wants it, the firm has control over this part of the supply chain. Hence it is obvious that even a firm that appears to be powerless, and to operate in a highly competitive market (i.e., even a maker of ball bearings in a competitive ball bearing market) will have power over a supply chain; such power is a prerequisite for the production of anything: one cannot produce a product without controlling the supply chain implicit in the product's production process.
} 


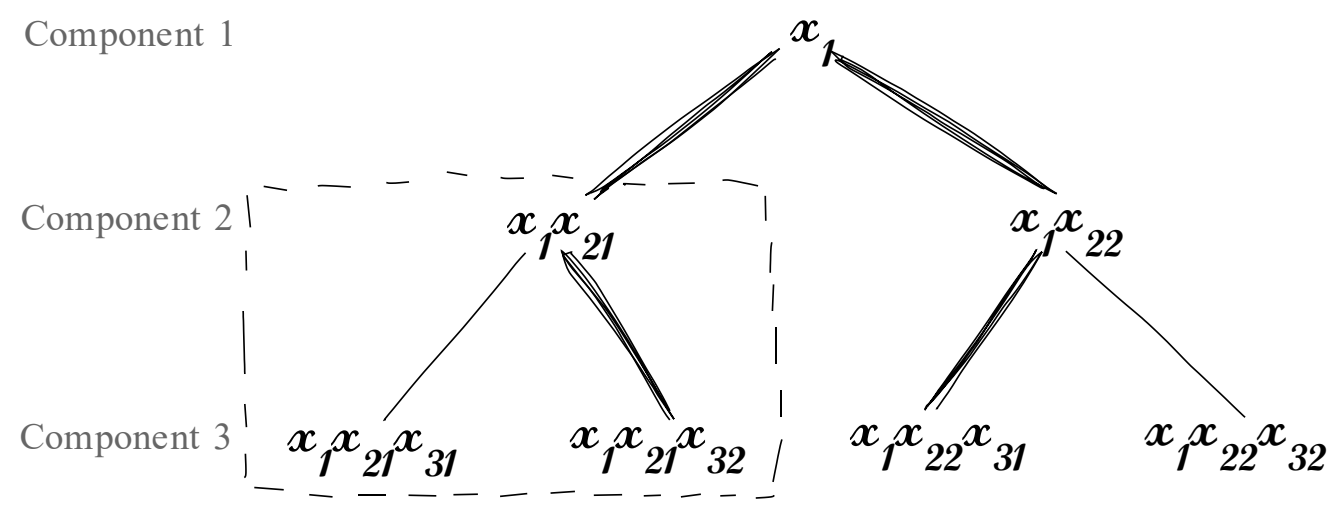

Figure 3

It may therefore be said that products are defined by the ambit of discrimination. Where an input controller desists from discrimination-or there is no controller to discriminate in the first place - new products begin and extend for so far as discrimination extends downstream from them into the supply chain, only to end where the input controller for these products chooses to desist from discrimination. Here yet new products are born and the process repeats until the end consumer is reached. Where a supply chain has multiple products, consumers have the power to choose which of those products is incorporated into the final product consumed by end consumers. The locations of the zones of nondiscrimination within the supply chain determine where the chain is snipped into pieces and consumers permitted to choose between different options for the parts, a bit the way the snip points in chromosomes during crossover in meiosis determines which traits are unbundled and can be recombined with different traits and which traits will remain tied to each other whatever the reproductive outcome. ${ }^{145}$ It follows from this definition of the product that the boundary of the firm is not defined by what the firm formally owns, or even by what it formally controls through contract rights, but rather by the levels of the supply chain that the firm chooses to control through discrimination in the supply of inputs. ${ }^{146}$

The same analysis can be applied recursively to the components employed in any particular supply chain analysis. ${ }^{147}$ For a given definition

\footnotetext{
145 See Bruce Alberts et Al., Molecular Biology of the Cell 1014-21 (1994).

${ }^{146}$ Cf. WILlIAMSON, supra note 139, at 196-97; SCHERER \& ROSS, supra note 60, at 190.

${ }^{147}$ For the problem of the infinitude of components, and hence choices, that go into the production of anything, see Fuller, supra note 133, at 72-73. Williamson appears untroubled by this aspect of production and indeed comfortable with the very ungranular breakdown of components into core components characterized by site-specific efficiencies, unintegrable components like natural resources, and borderline components for which the make or buy
} 
of component a supply chain has a certain number of levels, one for each component. But how are the components themselves produced? To answer that question it is necessary to move to a greater level of granularity in considering the supply chain, to peek within the atom that is the component. When that is done, it is immediately clear that each component itself consists of a number of subcomponents that can theoretically be arranged in a linear supply chain. Further, it is clear that, if the component is produced by a single firm, then the firm must control at least one of the subcomponents of the component and must have leveraged that control to dictate how the subcomponents are to be assembled into the component. Thus in Figure 2 there must be a tree within each node of the tree with a single path through that tree chosen, through discrimination in the supply of subcomponents, by the maker of that component. And within each of the subcomponents within the component, there must be yet another tree pruned by discrimination, and so on, ad infinitum. It follows that the overall number of components of the supply chain (including all subcomponents, sub-subcomponents, and so on) that are chosen through discrimination must be vastly greater in number than the number of market interfaces in the chain - the number of points at which components are supplied in nondiscriminatory fashion - and that production is therefore necessarily always mostly decided by sellers rather than by end consumers. A supply chain may be divided into a thousand or even ten thousand products (one for each market interface), but that always necessarily represents a negligible fraction of the number of components of the finished product, and consumers can therefore only really choose between arrangements of great agglomerations of components, never between individual components when component is defined at a high level of granularity.

Of course, it is rare that an input controller sits at the top of a linear supply chain, directing how downstream firms will assemble the product and watching its input gather components around it like a snowball running down a mountainside until it lands in the hands of buyers across a nondiscriminatory market interface. It is much more common that an input controller will contract with a bunch of suppliers for components and add components of its own - the input that is the source of the firm's power-to these components to produce the product. ${ }^{148}$ In selecting its suppliers, this input controller effectively picks winners in each component market, deciding which suppliers will contribute to production of the product and which not. ${ }^{149}$ Because there is no inherent directionality or order to any

decision requires careful study. See WILLIAMSON, supra note 139, at 97-98.

148 See Bernstein, supra note 67, at 605.

149 See U.S. Chamber of Commerce, America's Antitrust Laws: Myth v. Facts, 
supply chain - the requirement of nondiscrimination in input supply does not require that components be sold from market to market in any particular order - we can therefore think of the input controller as being at the bottom of the subchain in such cases, rather than at the top, using the controller's power to dictate to the input supplier of the controller's choice immediately above not to purchase inputs from the next level up but instead to insist that the seller of the firm's choice at that level sell directly to the input controller, and so on all the way up the chain until one achieves the hub and spoke relationship of multiple suppliers to a single producer with which we are familiar.

It follows from all this that proposals to prohibit firms, even big firms, from competing on their own platforms, make little sense. ${ }^{150}$ Such a rule, if applied generally, would insert a market interface between every input over which a firm has power-the platform - and the next level down in the supply chain, quite regardless whether giving consumers decision-making power over that level improves the product or not. ${ }^{151}$

\section{Antitrust Picks Winners}

Antitrust has an answer to the question whether discrimination in the supply of inputs is good or bad that is of the same basic form as antitrust's answer to the question whether input control - the acquisition of powershould be permitted. The answer is that discrimination should be permitted if it improves the end product enjoyed by consumers. ${ }^{152}$ And here again antitrust follows the principle of innovation primacy to avoid balancing the value of product improvements against the harm of higher prices that may result from the product improvement. ${ }^{153}$ Thus the evaluation of discriminatory exercises of power, like acquisitions of power, requires that judges pick winners, in the sense that they must decide whether the product created by the defendant's actions is good for consumers and should be

\footnotetext{
https://www.uschamber.com/antitrust-laws\#mvf (arguing that consumers, not firms pick winners).

${ }^{150}$ See Warren, supra note 115; Subcommittee on Antitrust, Commercial, and Administrative Law of the Committee on the Judiciary of the United States House of Representatives, supra note 72 , at 397 .

151 See A Douglas Melamed, A Missed Opportunity, CPI AnTITRust Chronicle SPECIAL EDITION 6, 2 (2021); HOVENKAMP, supra note 8, at 519 ("Nearly every product or service sold can be divided into components or parts. A coat can be sold without its buttons, a desk without its drawers and a jar of pickles can probably be sold without its lid. The market would come to a standstill, however, if the antitrust laws gave every customer a legal right to atomize his purchases as much as he chose.").

${ }^{152}$ See GIFFORD \& KUDRLE, supra note 89, at 28.

${ }^{153}$ See Woodcock, supra note 4, at 2311.
} 
preserved, or bad for consumers and should be condemned. ${ }^{154}$

Courts sometimes try to avoid picking winners by appealing to economists to measure the effect on consumer welfare of the challenged conduct. ${ }^{155}$ But consumer welfare, in the economic sense of the difference between a consumer's willingness to pay and price, rises when a defendant's conduct improves its product-making the product more desirable and therefore increasing willingness to pay-and goes down when the defendant's conduct degrades competitors' products, reducing consumers' willingness to pay. ${ }^{156}$ So asking economists to measure willingness to pay amounts to asking them to decide whether consumers prefer the defendant's product to the products competitors would have produced but for the challenged conduct. ${ }^{157}$ But predicting which products consumers will like best is precisely what it means to pick winners. ${ }^{158}$ That requires answering a counterfactual, and for all their pretense of looking at the data, economists have no better access to alternative states of reality than do judges. ${ }^{159}$

All discriminatory conduct differentiates the products sold by downstream firms, making some more desirable to consumers and others less desirable. The outright refusal to sell to some firms but not others drives down the quality of the products offered by the disfavored firms, for they now lack an important input, which means that their products are now less like the products sold by the favored firms than they were before. ${ }^{160}$ Any term of sale that has a disparate impact operates in the same fashion. ${ }^{161}$ The requirement that buyers pick up their orders here rather than there, for example, creates a transport cost for some but not for others (those who are near here) that forces up the prices for some downstream products but not for others, differentiating the products. ${ }^{162}$ The rule that discrimination must improve the product is the rule that the differentiation brought about by discrimination must involve making products different by making some

154 Cf. U.S. Chamber of Commerce, The Role and Responsibility of Antitrust 2, https://www.uschamber.com/antitrust-laws\#isnot.

155 See Maurice E. Stucke, Does the Rule of Reason Violate the Rule of Law?, 42 U.S. DAVIS L. REV. 1375, 1385-86 (2009).

156 See HAL R. VARIAN, InTERMEDIATE MicROECONOMICS: A MODERN APPROACH 247-52

(7th ed. 2006).

157 See Eugene Silberberg, The Structure of ECONOMics: A MATHEMATICAL AnAlysis 3-8 (2d ed. 1990).

${ }^{158}$ Cf. U.S. Chamber of Commerce, supra note 154, at 2.

${ }^{159} C f$. SiLBERBERG, supra note 157, at 3-8.

160 See Thomas G. Krattenmaker \& Steven C. Salop, Anticompetitive Exclusion: Raising Rivals' Costs To Achieve Power over Price, 96 YALE L.J. 209, 250 n.129 (1986).

${ }^{161}$ See id.

${ }^{162}$ See id. at 249-51. 
better, and not only making products different by making some worse. ${ }^{163}$ It is the rule that the discrimination in question must be necessary to improve some products. ${ }^{164}$ Differentiation causes consumers to favor some products and reject others. ${ }^{165}$ Antitrust insists that differentiation involve product improvement, so that the products favored by consumers are better products, not the same old products that merely appear better to consumers because other products have been degraded. ${ }^{166}$ In this way competition leads to product improvement and technology-driven economic growth. ${ }^{167}$ The principle of innovation primacy means that antitrust will accept conduct that both improves and degrades products without seeking to balance the magnitude of the improvement against the magnitude of the degradation, just as, in the context of acquisitions of power, antitrust will not balance the harms associated with the power created by input control against the benefits of a product improvement used to justify that control. ${ }^{168}$ But antitrust does require that the degradation that comes along with the improvement be unavoidable: there can be no less harmful way of improving the product. ${ }^{169}$

The rule that discrimination must improve the product makes it easy to determine the legality of each of the three ways in which firms seek to increase willingness to pay through discriminatory conduct. Discrimination aimed at product improvement is of course perfectly legal, because it improves the product. ${ }^{170}$ Discrimination aimed at disciplining downstream firms or acquiring information about willingness to pay is illegal unless it incidentally improves products. ${ }^{171}$ Disciplining and information acquiring behavior are not, it should be noted, condemned because of any direct harms they may inflict on consumers in the sense of enabling an input controller to extract more profits from consumers. The antitrust laws do not prohibit the charging of high prices - the mere act of profit taking - and a firm that pummels a downstream firm in order to induce it to pay a higher price that is then passed on to consumers, or integrates vertically in order to gather intelligence on consumers and thereby to charge them higher prices is trying to do no more than charge higher prices. ${ }^{172}$ Disciplining and information acquiring are condemned because in order to achieve those higher prices they

\footnotetext{
163 See Woodcock, supra note 4, at 2309-11.

164 See id.

165 See id.

166 See id.

${ }^{167}$ See id. at 2312-13.

168 See id.

169 See Hemphill, supra note 21, at 937-38.

${ }^{170}$ See GIFFORD \& KUDRLE, supra note 89, at 28.

${ }^{171}$ See id.

${ }^{172}$ See HovenKAMP, supra note 8, at 356-58.
} 
interfere in production processes to an end other than improving the products that are the outcome of those processes. When you mess with machinery to an end other than making it better, the result is very likely to be that the machinery will function less well than before. And that means that although the conduct may increase the profits that the input controller can extract from consumers, and so increase effective willingness to pay from the perspective of the input controller, the true willingness to pay of consumers is likely to be reduced in the process. ${ }^{173}$ Thus antitrust's regulation of the exercise of power is aimed primarily at defending the integrity of the production process - the organization of the supply chain - against attempts to obtain a larger share of the pie by reengineering the production process in ways that reduce the size of the pie.

But antitrust cannot carry out this mission if it cannot judge what constitutes a product improvement and what does not. The desire of judges to subcontract the picking of winners to economists has made antitrust litigation fabulously costly in recent years, for the experts cost money, leading to reductions in enforcement. ${ }^{174}$ The solution to the problem is for judges to show some courage, and take responsibility for picking winners by doing it themselves. ${ }^{175}$ There is nothing for judges to be embarrassed about, for they substitute their judgment for that of firms when they pick winners, never for that of consumers. ${ }^{176}$ An antitrust case regarding the exercise of power is always a challenge to the attempt of a seller to discriminate, and therefore to the attempt of a seller to pick winners itself. It is never a challenge to the decision of a firm not to discriminate and to leave it to end consumers to decide which components to integrate into a product. When firms pick winners, they do so both when the winners they pick are winners for consumers (the product improvement case) and when they are losers for consumers but winners for the firms (the cases of disciplining downstream firms and of information acquisition). The premise of the antitrust laws is that courts must separate the good pickings from the bad. ${ }^{177}$

\section{B. Legal Doctrine}

1. The Law of Monopolization

The foregoing theory of antitrust's regulation of power exercises is a sort

\footnotetext{
${ }^{173}$ See Woodcock, supra note 20, at 126-36.

${ }^{174}$ See Stucke, supra note 155.

${ }^{175}$ Cf. U.S. Chamber of Commerce, supra note 154, at 2.

${ }^{176} C f$. Robert H Bork, The ANTITRUST PARADOX: A POLICY AT WAR With ITSELF 90-91 (1978).

${ }^{177}$ Cf. U.S. Chamber of Commerce, supra note 154, at 2.
} 
of best-fit line for antitrust's rules on power exercise. ${ }^{178}$ Like any such line, it is not always coincident with the law applied in particular cases, and at points addresses issues that have not yet been addressed by the courts. ${ }^{179}$ The heart of actual antitrust doctrine on the exercise of power is the monopolization claim, which has a general structure that is repeated in various forms throughout the antitrust law of power exercises. ${ }^{180}$ A claim of monopolization, which is brought under Section 2 of the Sherman Act, has three elements: conduct that creates harm to competitors, concomitant harm to consumers, and monopoly power. ${ }^{181}$ The first two elements are sometimes applied in a burden-shifting framework in which the plaintiff first alleges "anticompetitive conduct," which is code for harm to competitors despite the tendency of judges to distinguish the terms "competition" and "competitors" in other contexts. ${ }^{182}$ The defendant then rebuts by showing a procompetitive justification, which is code for showing that consumers were made better off by the action, rather than harmed. ${ }^{183}$ The plaintiff then has the opportunity to rebut the procompetitive justification. ${ }^{184}$

This test tracks the theory in places. As will become clear from the cases to be discussed below, plaintiffs prove harm to competitors by showing discrimination in inputs that harms downstream firms. Defendants show a procompetitive justification by showing a product improvement. Theory suggests that the monopoly power requirement should compel a showing of power in the input denied to competitors, because it is control over an input that makes the exercise of power possible. But here practice diverges from theory. Curiously, antitrust instead requires proof of power in the downstream market, rather than in the input market, usually by showing a market share of around $75 \%$ in that market. ${ }^{185} \mathrm{~A}$ consequence of this peculiar requirement is that monopolization claims can only be brought when the defendant actually owns the downstream operations that the defendant favors through discriminatory supply of inputs (although, as we shall see, a monopolization claim that piggybacks on exclusive dealing can be based on a contractual relationship with a downstream firm). ${ }^{186}$ This is not to say that

\footnotetext{
178 See CHRISTOPHER DOUGHERTY, InTRODUCTION TO ECONOMETRICS 46 (3d ed. 2007).

${ }^{179}$ See id.

${ }^{180}$ See HoVENKAMP, supra note 8, at 349-51.

${ }^{181}$ See United States v. Microsoft Corp., 253 F. 3d 34, 58-59 (D.C. Cir. 2001).

182 See id.; Brunswick Corp. v. Pueblo Bowl-O-Mat, Inc., 429 U.S. 477, 488 (1977).

${ }^{183}$ See United States v. Microsoft Corp., 253 F. 3d at 58-59.

${ }^{184}$ See United States v. Microsoft Corp., 253 F. 3d 34.

185 See HOVENKAMP, supra note 8, at 352-54.

186 See AREEDA \& HOVENKAMP, supra note 7, III 650c, 770 (noting that the challenged conduct must have contributed to the creation or maintenance of the monopoly power enjoyed by the defendant and rejecting the notion that there should be liability for a refusal
} 
courts do not insist that plaintiffs prove input control. But courts often address input control informally, by concluding, for example, that the input is essential without undertaking extensive market analysis to reach that conclusion. ${ }^{187}$ Because courts effectively require that the defendant own the downstream firm, courts have not tended to appreciate that an input controller may be able to wreck the supply chain just as effectively through the use of discrimination to pick independent favorites in the downstream market as through the use of discrimination to favor its own downstream operations. ${ }^{188}$

Courts also have struggled to appreciate that any supply terms that fall short of explicitly denying access to the input to downstream firms, but which nevertheless have a disparate impact on them, should count as anticompetitive conduct for purposes of the burden shifting test. Instead, courts have tended to see complete denial of an input to a competitor as the archetypal form of discrimination, calling it a "refusal to deal," and have struggled even to accept that other kinds of formally discriminatory sales terms, such as selling a lower quality product to disfavored firms or charging them a higher price, much less facially neutral policies that have a disparate impact, can be just as discriminatory as refusing to sell at all. ${ }^{189}$ (We shall see that in the antitrust law of intrabrand vertical restraints the courts have proven much more open minded about the meaning of discrimination and even accept facially neutral sales terms that have a disparate impact as anticompetitive conduct. ${ }^{190}$ )

to deal by a vertically unintegrated firm).

187 See Aspen Skiing Co. v. Aspen Highlands Skiing Corp., 472 U.S. 585, 594 (1985) ("Without a convenient all-Aspen ticket, Highlands basically "becomes a day ski area in a destination resort."”).

${ }^{188}$ Amazon's decision to stop listing antiquarian booksellers from high-cost countries on its Abebooks platform is a good example. See David Streitfeld, Booksellers Protest Amazon Site's Move to Drop Stores From Certain Countries, N.Y. TimES (Nov. 4, 2018), https://www.nytimes.com/2018/11/04/technology/abebooks-amazon-protest-

booksellers.html. Amazon does not itself sell antique books for its own account and so Amazon does not compete in the antique book market. But Amazon did stand to profit from discriminating in the supply of its platform input and the consequences for the supply chain were drastic: certain booksellers were forced from the market, or at least became harder for consumer to access. The key question, then, is not whether Amazon itself competed in the antiquarian book market but whether its favoring of booksellers in low-cost countries improved the end product - antique books, the value of which should be measured as the difference between book quality and the prices at which the books is sold-for consumers. If the cost reductions were passed on to consumers, then the answer might be yes.

${ }^{189}$ See Pacific Bell Telephone v. Linkline Comm., 555 U.S. 438, 1118-19 (2009); Verizon Commc'ns Inc. v. Law Offices of Curtis V. Trinko, 540 U.S. 398, 410-11 (2004).

${ }^{190}$ See Graphic Products Distributors v. Itek Corp., 717 F. 2d 1560, 1564-65, 1578 (Court 


\section{a. Lorain Journal}

But the courts' blind spot regarding the full scope of discrimination aside, the courts do always require a showing of discrimination in monopolization cases, if the history of actually-decided monopolization cases is any guide. For discrimination, in the form of facially-discriminatory terms of sale, and usually an outright refusal to sell, can be found in all monopolization cases if one looks carefully. Consider that most enigmatic of monopolization cases, Lorain Journal Co. v. United States. ${ }^{191}$ The Supreme Court condemned the only paper in the city of Lorain, Ohio for refusing to run advertisements by advertisers who also advertised on the local radio station. ${ }^{192}$ At first glance, there is no discrimination in the supply of inputs to downstream firms here. While, as the Court recognized, the paper refused to deal with its customers - ad buyers - under certain conditions, the paper did not discriminate in its relationship with the radio station or any other downstream firm. ${ }^{193}$

The key to identifying the discriminatory conduct in Lorain Journal is to recognize that consumers sometimes assemble product components on their own rather than buy the assembled product directly from the market. ${ }^{194}$ This does not eliminate the linear supply chain that is latent in all production, but it does mean that an input controller's discriminatory supply of inputs can take the form of a refusal to supply inputs to consumers who assemble the final product themselves rather than the form of a refusal to supply inputs to a downstream competitor that assembles the final product and sells it along to end consumers.

Now, the Court in Lorain Journal made clear that some amount of newspaper advertising was an essential input into the promotional mix purchased by advertisers. ${ }^{195}$ But advertisers also chose to supplement necessary print advertising with additional advertising, which might be additional print advertising or radio advertising. ${ }^{196}$ Thus the input at issue in the case was "necessary print advertising" and the product actually consumed by advertisers was "necessary print advertising plus some top-up advertising," whether print or radio, as shown in Figure 4. The paper's refusal to supply print to radio advertisers therefore amounted to the denial of an essential input - print advertising - to the radio station, for what

\footnotetext{
of Appeals, 11th Circuit 1983).

${ }^{191}$ Lorain Journal Co. v. United States, 342 U.S. 143 (1951).

192 See id. at 152-56.

${ }^{193}$ See id.

${ }^{194}$ See HovenKAMP, supra note 8, at 537-40.

${ }^{195}$ See Lorain Journal Co. v. United States, 342 U.S. at 152-56.

${ }^{196}$ See id.
} 
advertisers consumed in buying radio advertising was in fact a full promotional mix that necessarily included print advertising, and the paper's actions made consumption of the print-plus-radio mix impossible.

But because, in the peculiar advertising market that existed in Lorain, consumers (advertisers) happened to buy the components of their advertising mix separately and assemble them on their own, this input denial was manifest in a refusal to sell advertising directly to consumers, rather than in a refusal to sell to the downstream competitor, the radio station, in the market to supply the full promotional mix consisting of necessary print advertising plus top-up advertising to consumers. ${ }^{197}$ If instead it had been the practice of the radio station to buy print ad space and bundle it with radio advertising, then the paper would have been forced more clearly to refuse to deal with a downstream competitor by refusing to supply print advertising directly to the radio station. ${ }^{198}$ Though formally different, the two scenarios exhibit exactly the same kind of discrimination through input denial. Thus Lorain Journal is, after all, a monopolization case premised on discrimination by an input controller.
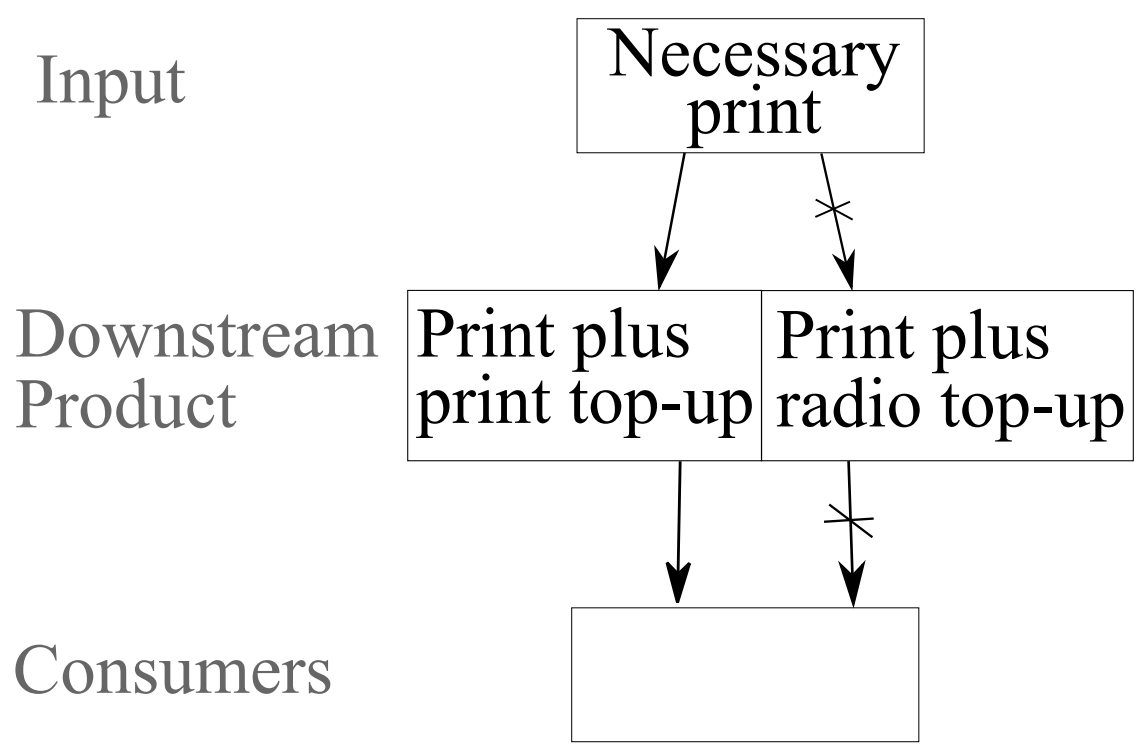

Figure 4

Once the input denial in Lorain Journal is properly appreciated, it becomes clear that Lorain Journal is no sui generis case, as Robert Bork

\footnotetext{
${ }^{197}$ See id.

${ }^{198}$ Cf. id.
} 
seemed to believe. ${ }^{199}$ Bork praised the case while attacking all other monopolization cases presumably because he thought Lorain Journal was special: telling your customers not to buy from a competitor seems uniquely evil. $^{200}$ In fact, Lorain Journal is but a run-of-the-mill example of discrimination through input denial, no different than any of the other monopolization cases shortly to be discussed in this Article. Like all monopolization cases - indeed all cases challenging the exercise of powerthe question posed by the case is whether the discriminatory conduct improved the product. ${ }^{201}$ Bork's intuition that Lorain Journal was rightly decided likely springs not from the fact that the conduct was somehow different in kind from other monopolizing conduct and somehow worse-it was not-but rather from the fact that making all advertisers use print only, rather than print-plus-radio, so obviously does not improve a product, and indeed seems only to degrade and eliminate the print-plus-radio product that advertisers seem to have preferred. ${ }^{202}$ That is, Bork likely thought the case special because the consumer harm was clear, not because the mode of anticompetitive conduct - telling your customers not to deal with your competitors - was any different from the refusals to sell inputs to competitors that are so common in monopolization cases. ${ }^{203}$

Bork might better have understood this if he had actually carried out an economic analysis of the case, as he himself often called for courts to do. ${ }^{204}$ If print-plus-radio advertising was a better product than print alone, why would the paper, which controlled an essential input and could simply have extracted any excess profits generated by the radio station's sale of a superior product merely by charging a higher price for the print input, have chosen to destroy the product? ${ }^{205}$ The answer might be that radio was a nascent competitor to print advertising in Lorain, one that might become an essential part of any advertiser's promotional mix in the future, and thereby break the paper's lock on the essential part of advertisers' promotion mixes. ${ }^{206}$ The

\footnotetext{
199 See William E. Kovacic, Out of Control? Robert Bork's Portrayal of the US Antitrust System in the 1970s, 79 ANTITRUST L.J. 855, 860 (2014); Leon B. Greenfield, Lorain Journal and the Antitrust Legacy of Robert Bork Symposium: Robert Bork and Antitrust Policy: Afterword, 79 ANTITRUST L.J. 1047, 1049-50 (2014); BORK, supra note 176, at 344-46.

200 See Kovacic, supra note 199, at 860; Greenfield, supra note 199, at 1049-50; BORK, supra note 176, at 345 (stating that Lorain Journal "clearly displayed predatory intent").

${ }^{201}$ See GIFFORD \& KUDRLE, supra note 89, at 28.

202 See BORK, supra note 176, at 346 (observing that "no efficiency defense was offered" in Lorain Journal).

${ }^{203}$ See id. at 176.

${ }^{204}$ See RoBert H. Bork, The Antitrust PARAdOX: A POliCy AT WAR With ItSElf 134

(2d ed. 1993).

${ }^{205}$ See Director \& Levi, supra note 136, at 290.

${ }^{206}$ See Elhauge, supra note 92, at 417-18.
} 
paper probably could not indemnify itself against the profit reductions that would result by billing the radio station for them now - the station might refuse to negotiate - and so the paper might have decided to smash the radio station and open a station of its own in future. ${ }^{207}$ The paper was clearly discriminating not to improve products but only to increase profits.

Lorain Journal is also remarkable in that the court actually applied the monopoly power test rationally in that case, treating the paper's share of the print advertising market as indicative of power, rather than, as today's monopolization test would require, treating the paper's share of the downstream necessary-print-plus-top-up market as indicative of power. ${ }^{208}$ Since print advertising is the input in this case, it made sense to examine the level of the paper's control over that input. ${ }^{209}$ By contrast, as it has evolved, the monopolization claim would today require proof of monopoly power in the downstream market - the market from which competitors are excludedwhich here would be the market for the full advertising mix, as the radio station was certainly not competing in the print advertising market. ${ }^{210}$ If radio were a popular top up, or if advertisers commonly used billboard advertising as a top-up in lieu of either print or radio, then it is possible that the paper did not have power in the downstream market.

\section{b. Aspen Skiing}

Other monopolization cases are more straightforward. In Aspen Skiing Co. v. Aspen Highlands Skiing Corp., the defendant ski mountain owner refused to sell lift tickets to another mountain owner who wished to bundle them with passes to its own mountain and thereby offer customers an allmountain bundle that would allow them to pay once to gain access to all of the skiing in the area. ${ }^{211}$ Like print advertising for advertisers in Lorain, the defendant's tickets were necessary, here for skiers visiting Aspen, because the defendant owned three of the four ski mountains in Aspen: few would choose to ski the fourth mountain alone and bypass the other three. ${ }^{212}$ And like radio advertising for advertisers in Lorain, the fourth mountain-owned by the plaintiff - was for Aspen skiers a top-up that they would like to use in addition to the other three mountains if getting access would not be too difficult. $^{213}$ The input at issue in Aspen Skiing was therefore access to the

\footnotetext{
${ }^{207}$ See Cooter, supra note 91, at 15-20.

${ }^{208}$ See Lorain Journal Co. v. United States, 342 U.S. 143, 152-56 (1951).

209 See id.

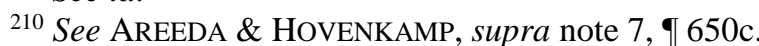

${ }^{211}$ Aspen Skiing Co. v. Aspen Highlands Skiing Corp., 472 U.S. 585, 605-11 (1985).

${ }^{212}$ See id.

${ }^{213}$ See id.
} 
three mountains owned by the defendant and the downstream product was access to those three mountains plus a top-up, which could just be more skiing on the three mountains or skiing the fourth mountain owned by the plaintiff as well. This is shown in Figure 5.

\section{Input \\ Consumers}

Three-mountain tickets

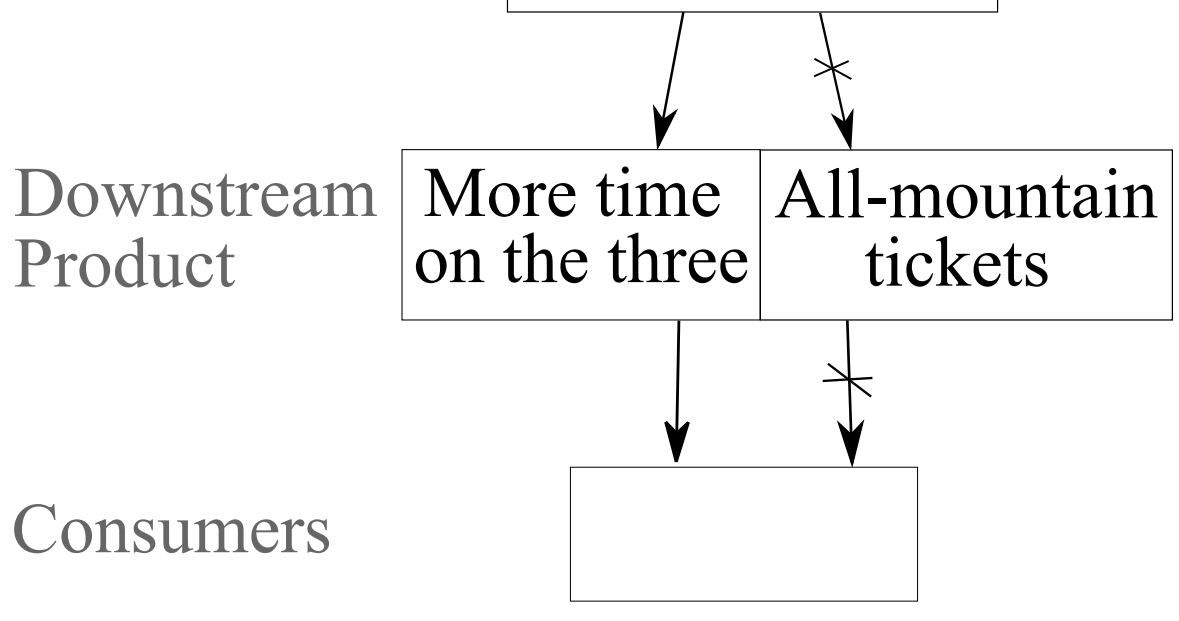

Figure 5

Unlike in Lorain Journal, however, in Aspen Skiing consumers did not assemble the end product on their own and indeed were unwilling to do so. ${ }^{214}$ Skiers could buy tickets to all four mountains separately, but they rarely did that. ${ }^{215}$ Instead, they purchased all-mountain passes. ${ }^{216}$ When the defendant subsequently refused to supply lift tickets to the plaintiff to permit the plaintiff to continue to assemble and sell all-mountain passes to skiers, the defendant engaged in input denial directly with its downstream competitor, the plaintiff in the case, making Aspen Skiing a straightforward example of the role of discrimination via input denial in monopolization cases.

c. Trinko and Linkline

Consistent with the modern focus on product improvement, the Court in Aspen Skiing emphasized that consumers preferred the all-mountain pass. ${ }^{217}$

\footnotetext{
${ }^{214}$ See id.

215 See id.

${ }^{216}$ See id.

${ }^{217}$ See id.
} 
This was a picking of winners. The Court could have decided instead that skiing in the area is more enjoyable when skiers do not waste time tramping over to a fourth mountain and instead devote more of their visit to drinks at the lodge. ${ }^{218}$ The fact that such an argument appears quite absurd shows how inhospitable the facts were to product improvement rationales. ${ }^{219}$ The Court has since, however, seemed to lose its nerve, sidestepping the picking of winners in part by binding itself to the silly rule that a firm that discriminates from the first moment it enters the market must be improving its product. ${ }^{220}$

In Verizon Commc'ns Inc. v. Law Offices of Curtis V. Trinko, a telephone company supplied access to its network on discriminatory terms to firms that competed downstream with the company to connect calls. ${ }^{221}$ The company degraded competitors' call quality but not, of course, its own. ${ }^{222}$ Similarly, in Pacific Bell Telephone v. Linkline Commc'ns, a different phone company harmed downstream competitors in the market to provide DSL internet access by charging competitors an above-cost price for access to its network, something that is necessarily discriminatory because a firm can supply inputs to itself only at cost. ${ }^{223}$ Instead of addressing the question whether the input denial in these cases improved the downstream product offered to consumers - something that might well have been true in both cases given the technological difficulty of opening phone networks to outsiders- the Court chose instead to appeal to the arbitrary principle that discrimination must be new - that it must represent the termination of a prior profitable course of dealing - before the court will entertain the notion that it might fail to be product improving. ${ }^{224}$ The assumption seems to be that if a firm always has discriminated in the past then that must be because the discrimination improves the product. ${ }^{225}$ Of course the explanation could just as easily be that the discrimination always did aid in the disciplining of downstream firms or the acquisition of information, both of which likely degrade

\footnotetext{
${ }^{218}$ In fact, the defendant argued unsuccessfully that it did not want to be associated with the fourth mountain because it was of inferior quality. See id. at 609-10.

219 See id. at 608-10.

${ }^{220}$ See Mark S. Popofsky \& Ariel A. Martinez, Section 2 and the Rule of Reason: Report from the Front, CPI ANTITRUST CHRONIClE (Mar. 2016), at 2-3, https://www.competitionpolicyinternational.com/wp-content/uploads/2016/03/Section-2and-the-Rule-of-Reason.pdf.

${ }^{221}$ See Verizon Commc'ns Inc. v. Law Offices of Curtis V. Trinko, 540 U.S. 398, 407-11 (2004). 222 See id.

${ }^{223}$ See Pacific Bell Telephone v. Linkline Comm., 555 U.S. 438, 1118-20 (2009).

${ }^{224}$ See Trinko, 540 U.S. at 407-11; Pacific Bell Telephone v. Linkline Commc'ns, 129 S. Ct. 1109, 1118-20 (2009).

225 See Trinko, 540 U.S. at 407-11.
} 
products rather than improve them. ${ }^{226}$

d. Qualcomm

Understanding monopolization cases as being fundamentally about discrimination helps explain one of the most confusing monopolization cases since Lorain Journal. In FTC v. Qualcomm Inc., the chipmaker defendant controlled an essential input-patents essential to making or using certain kinds of smart phone chips - required by chip buyers in order to incorporate the chips into the smartphones that the buyers manufacture. ${ }^{227}$ Thus the input market was the license market, the downstream market was the market for the chips-plus-licenses bundle, and the consumers were the smartphone makers, as shown in Figure 5. ${ }^{228}$ The FTC charged initially that Qualcomm's insistence on selling licenses directly to smartphone markers, instead of supplying them to rival chip makers, constituted an anticompetitive refusal to deal, but that was an incorrect characterization of the case. ${ }^{229}$ For, as in Lorain Journal, the smartphone-maker consumers in Qualcomm were perfectly happy to assemble the bundle of chips and licenses on their own, and so there was no real refusal to supply licenses to rival chipmakers. ${ }^{230}$ Those rival chipmakers got their license input, albeit delivered directly to consumers rather than supplied to the chipmakers who would then bundle it with their chips and sell it along to consumers.

But the fact that Qualcomm did not deny the input entirely to competitors does not mean that there was no monopolization case, only that the discrimination that served as the anticompetitive conduct was not outright input denial. The failure of both sides fully to appreciate this reflects the broader failure of antitrust to recognize that discrimination, not just the narrow subcategory of refusals to deal, is the heart of anticompetitive conduct. ${ }^{231}$ The discrimination that harmed competitors in Qualcomm was instead Qualcomm's charging of discriminatory prices to chipmaker rivals through the medium of the above-cost prices Qualcomm charged for its licenses to consumers. ${ }^{232}$

\footnotetext{
${ }^{226}$ See supra Section IV.A.2.

${ }^{227}$ See FTC v. Qualcomm Inc., No. 19-16122, slip op. at 10, 31-36 (9th Cir. Aug. 11, 2020).

${ }^{228}$ See id.

${ }^{229}$ See id.

${ }^{230}$ See id.

${ }^{231} C f$. AREEDA \& HovenKAMP, supra note 7, II 770 (rejecting the notion that discriminatory supply of inputs should count as monopolization as a general matter); Pacific Bell Telephone v. Linkline Comm., 555 U.S. 438, 1118-20 (2009).

${ }^{232}$ See Brief of Amici Curiae Law and Economics Scholars in Support of Appellee and Affirmance at 7-11, FTC v. Qualcomm, Inc., No. 19-16122 (9th Cir. 2019).
} 
The above-cost prices Qualcomm charged for licenses were not on their face discriminatory, because Qualcomm charged the same license prices regardless whether consumers purchased Qualcomm chips to go along with the licenses or purchased rivals' chips instead. ${ }^{233}$ But the above-cost prices were in fact discriminatory because a firm always necessarily supplies inputs to itself at cost, even when consumers assemble the end product. ${ }^{234}$ As Qualcomm's license prices increased above cost, Qualcomm could reduce the prices it charged for its chips, because Qualcomm would recoup any losses through the extra profits it earned on the licenses. ${ }^{235}$ As a result, the above-cost license prices did not change the overall cost to consumers of buying their chips-plus-licenses bundles from Qualcomm. ${ }^{236}$ But the abovecost license prices did change the overall cost of buying the chips-pluslicenses bundles from rival chip makers, for the rival chip makers did not sell licenses and so could not use excess profits from licenses to subsidize lower prices for chips. ${ }^{237}$ As a result, the high prices Qualcomm charged for chips drove up the cost of chips-plus-licenses bundles sold by rivals but not the cost of the bundles sold by Qualcomm. ${ }^{238}$ Of course, neither Qualcomm nor rival chip makers actually sold chips-plus-licenses bundles to consumers. ${ }^{239}$ Qualcomm sold the licenses separately from chips and consumers assembled the bundles on their own, but the effect was the same as it would have been were Qualcomm to sell licenses to rival chipmakers, instead of directly to consumers and to charge high prices for the licenses sold to rival chip makers. ${ }^{240}$ This made Qualcomm conceptually identical to Linkline, in which

\footnotetext{
${ }^{233}$ See FTC v. Qualcomm Inc., No. 19-16122, slip op. at 10, 31-36.

${ }^{234}$ A firm necessarily always supplies inputs to itself at cost because any payment that a firm's downstream subsidiary makes to the firm counts toward the revenues of the entire firm, including its subsidiaries, and so can be netted out of overall firm revenues, whereas production costs leave the firm and so persist. Thus the cost to the subsidiary of an input purchased from the firm is the cost of production of the input, since that is the cost of the input to the overall firm of which the subsidiary is a part, but any payment the subsidiary makes to the firm for the input is just a payment from self to self, and so is no cost at all to the firm.

Now, Qualcomm did not supply patent licenses directly to itself; there was no Qualcomm subsidiary buying licenses and combining them with chips for resale to consumers. Qualcomm instead sold the input and the downstream product separately to consumers who assembled them into a finished product on their own. But the fact of consumer assembly does not change the analysis, as the remainder of this paragraph explains.

235 See Brief of Amici Curiae Law and Economics Scholars in Support of Appellee and Affirmance at 7-11, FTC v. Qualcomm, Inc., No. 19-16122.

${ }^{236}$ See id.

${ }^{237}$ See id.

${ }^{238}$ See id.

${ }^{239}$ See FTC v. Qualcomm Inc., No. 19-16122, slip op. at 10, 31-36 (9th Cir. Aug. 11, 2020).

${ }^{240}$ See id.
} 
the telephone company charged above-cost prices for the network access input to competing DSL providers, but for the fact that consumer assembly in Qualcomm meant that the high prices were actually charged to consumers. ${ }^{241}$

The FTC seemed to grasp that the above-cost prices charged for licenses were anticompetitive, but inexplicably resisted the analogy to Linkline. ${ }^{242}$ The reason may have been fear that the courts would follow the suggestion in Linkline and Trinko that the absence of a termination of a prior profitable course of dealing signals product-improving conduct. ${ }^{243}$ But the Ninth Circuit relied on prior-profitable-course-of-dealing thinking anyway to reject the FTC's misguided input denial claim. ${ }^{244}$ That is a shame, because no appeal to prior-profitable-course-of-dealing thinking would have been needed here if the FTC had insisted that the discriminatory conduct was Qualcomm's pricing, for Qualcomm conceded that its only motive for charging high license fees was to increase its profits, rather than to improve its products. ${ }^{245}$ This admission would not have been enough to seal a win for the FTC because Qualcomm might have been able to take advantage of antitrust immunity for pricing practices designed to do no more than extract profits in the sense of maximizing them given prevailing willingness to pay. ${ }^{246}$ But to win, the FTC would have had only to show that the pricing was instead genuinely discriminatory conduct: that the prices were high enough to drive rival chipmakers from the market to the end of increasing consumer willingness to pay. ${ }^{247}$ That is, the FTC would have needed only to show that Qualcomm charged supra-monopoly prices rather than just monopoly prices. ${ }^{248}$

\section{e. Amazon}

Any case against Amazon predicated on the company's treatment of third-party sellers on the company's ecommerce platform has both theoretical

\footnotetext{
${ }^{241}$ See Pacific Bell Telephone v. Linkline Comm., 555 U.S. 438, 1118-20 (2009); FTC v. Qualcomm Inc., No. 19-16122, slip op. at 31-36.

${ }^{242}$ Petition of the Federal Trade Commission for Rehearing En Banc at 12 n.6, FTC v. Qualcomm Inc., No. 19-16122 (9th Cir. 2020).

243 See Pacific Bell Telephone v. Linkline Comm., 555 U.S. at 1118-20; Verizon Commc'ns Inc. v. Law Offices of Curtis V. Trinko, 540 U.S. 398, 407-11 (2004); Popofsky \& Martinez, supra note 220 , at 2-3.

${ }^{244}$ See FTC v. Qualcomm Inc., No. 19-16122, slip op. at 31-36.

245 See id. at 50-51.

${ }^{246}$ See id. at 34 nn. 15, 50-51; supra Section IV.A.1.

${ }^{247}$ See supra IV.A.3.

${ }^{248}$ See supra IV.A.3.
} 
and practical problems. ${ }^{249}$ Amazon does discriminate in the way the company supplies the ecommerce platform services input that Amazon controls to downstream firms that wish to retail goods on Amazon.com. The company displays advertisements for the retail products that Amazon manufactures and sells on the platform more prominently than Amazon displays the advertisements of third-party sellers, for example. ${ }^{250}$ And Amazon's platform services are likely to be essential for many sellers, given Amazon's large share of ecommerce and growing importance of online shopping relative to brick-and-mortar retail, making harm to competitors from the discrimination quite likely. ${ }^{251}$ But it is not at all clear that Amazon's discrimination fails to improve Amazon's products. ${ }^{252}$ In recent years, Amazon has had trouble keeping fake and defective products off of its platform. ${ }^{253}$ It could be the case that Amazon finds it easier to ensure that its own manufactured products meet safety criteria than to ensure that third party sellers' products meet those criteria, in which case advertising that promotes Amazon's products might constitute a product improvement from the perspective of Amazon customers, who can use the advertising to make sure that they identify Amazon's own, presumably more-reliable, offerings every time they use the site. ${ }^{254}$

On a practical level, a case against Amazon faces not only the challenge of establishing consumer harm - the absence of a product improvement - but also the challenge of proving monopoly power in the downstream market, that quirk of monopolization law that is not supported by theory but nevertheless essential to winning cases. ${ }^{255}$ There is not, however, one downstream market for Amazon, but thousands, one for each product that

\footnotetext{
${ }^{249}$ Cf. Subcommittee on Antitrust, Commercial, and Administrative Law of the Committee on the Judiciary of the United States House of Representatives, supra note 72, at 247-329, 377-83.

${ }^{250}$ See, e.g., Jay Greene, Amazon Sellers Say Online Retail Giant is Trying to Help Itself, Not Consumers, WASH. POST (Oct. 2019), https://www.washingtonpost.com/technology/2019/10/01/amazon-sellers-say-online-retailgiant-is-trying-help-itself-not-consumers/; Julie Creswell, How Amazon Steers Shoppers to Its Own Products, N.Y. TIMES, https://www.nytimes.com/2018/06/23/business/amazon-thebrand-buster.html (last visited Sep. 13, 2019).

${ }^{251}$ See, e.g., Greene, supra note 250.

252 See GIFFORD \& KUDRLE, supra note 89, at 28.

${ }^{253}$ See Alexandra Berzon Scheck Shane Shifflett and Justin, Amazon Has Ceded Control of Its Site. The Result: Thousands of Banned, Unsafe or Mislabeled Products, WALL ST. J. (Aug. 23, 2019), https://www.wsj.com/articles/amazon-has-ceded-control-of-its-site-theresult-thousands-of-banned-unsafe-or-mislabeled-products-11566564990.

254 This advertising would be informative, unlike most advertising in the information age. See Woodcock, supra note 4, at 2299-2308.

${ }^{255}$ See HovenKAMP, supra note 8, at 352-54.
} 
Amazon manufactures and sells on its site. ${ }^{256}$ Third-party sellers would need to show that Amazon-branded products have a large market share in each such market in order to prevail with respect to that market. ${ }^{257}$ That is likely to be true only for a few of Amazon's manufactured products. ${ }^{258}$ For this reason, it is perplexing that Amazon's critics have not challenged the company's practice of retailing goods manufactured by others on its platform for its own account. Amazon's overall retail share of markets on Amazon.com, including sales for its own account of its own brands and other brands, is larger than its manufactured share of markets, although, even then, probably not large enough to meet the monopoly power requirement except in select markets. ${ }^{259}$

Critics have not only pushed for monopolization claims to be brought against Amazon but also for a rule that would prohibit Amazon from competing on its own platform. ${ }^{260}$ The argument that Amazon should not be permitted to compete on its own platform, because that creates a conflict of interest in Amazon's dealings with third-party sellers, is naïve at best. ${ }^{261}$ To the extent that Amazon is able to use discriminatory conduct to improve its products, there is no conflict of interest between Amazon and consumers,

\footnotetext{
${ }^{256}$ See Woodcock, Digital Monopoly without Regret, supra note 119, at 56-58.

257 See id.

258 See All You Need to Know About Amazon's Private Label Brands, PATTERN, https://pattern.com/blog/all-you-need-to-know-about-amazons-private-label-brands/ (last visited Feb. 27, 2021) (reporting data from Amazon showing that, across consumer electronics, beauty, home \& kitchen, softlines, books, consumables, and toys categories, Amazon's own private label brands have no more than a 9\% share of sales in any one category); Subcommittee on Antitrust, Commercial, and Administrative Law of the Committee on the Judiciary of the United States House of Representatives, supra note 72, at 275 (presenting the same data in graph form). Indeed, more than 55\% of units sold on Amazon.com were sold by third-party sellers in 2020, suggesting that Amazon's market share in individual Amazon.com product markets is low as a general matter. See Amazon: Third-Party Seller Share 2020, STATISTA, https:/www.statista.com/statistics/259782/thirdparty-seller-share-of-amazon-platform/ (last visited Feb. 27, 2021).

259 See All You Need to Know About Amazon's Private Label Brands, supra note 258 (reporting data from Amazon showing that, across consumer electronics, beauty, home \& kitchen, softlines, books, consumables, and toys categories, Amazon's total sales for its own account, including both private label brands and non-Amazon brands, exceeded $43 \%$ of total sales on Amazon.com in any one category only for books, for which Amazon's sales were $74 \%$ of sales on Amazon.com in that category); Subcommittee on Antitrust, Commercial, and Administrative Law of the Committee on the Judiciary of the United States House of Representatives, supra note 72, at 275.

${ }^{260}$ See Warren, supra note 115; Subcommittee on Antitrust, Commercial, and Administrative Law of the Committee on the Judiciary of the United States House of Representatives, supra note 72 , at $377-83$.

${ }^{261}$ See Subcommittee on Antitrust, Commercial, and Administrative Law of the Committee on the Judiciary of the United States House of Representatives, supra note 72, at 377-83.
} 
only between Amazon and third-party sellers that sell inferior products. ${ }^{262}$ Moreover, Amazon would still have an interest in discriminating against goods sold by third party sellers and in favor of goods Amazon itself retails on the platform even were Amazon to cease to sell goods that Amazon makes itself. ${ }^{263}$ What is more, even were Amazon to desist from retailing goods manufactured by others on its platform, Amazon would still have an incentive to discriminate against some third party sellers but not others, depending upon the profitability of the sellers to Amazon. ${ }^{264}$ Thus a rule prohibiting Amazon from competing on its own platform would not eliminate the conflict of interest between Amazon and sellers that Amazon chooses to disfavor. ${ }^{265}$

\section{f. Apple}

Cases alleging that Apple discriminates against app developers by preventing consumers from installing unapproved apps on their phones are even more problematic than a case against Amazon, for the only reason for which app developers wish that consumers could install their apps without approval is that then the apps would not be subject to the fees that Apple normally charges developers for access to the iPhone. ${ }^{266}$ Thus the cases amount to the demand that Apple supply its input - iPhone access - for free or at a reduced price. The cases therefore challenge Apple's antitrust-immune right to use price to extract the maximum possible profits from downstream firms given their current willingness to pay. ${ }^{267}$ There is no suggestion in the cases that Apple uses discrimination to increase willingness to pay. ${ }^{268}$ Thus there is no real anticompetitive conduct in the cases, much less consumer harm. Even monopoly power in the peculiar sense in monopolization cases of power in the downstream market is lacking, for Apple makes few apps itself and those do not compete with the apps made by plaintiffs in the

\footnotetext{
${ }^{262}$ See Brunswick Corp. v. Pueblo Bowl-O-Mat, Inc., 429 U.S. 477, 488 (1977).

${ }^{263}$ See supra Section IV.A.3.

${ }^{264}$ See supra Section IV.A.3.

${ }^{265}$ Cf. Hovenkamp, supra note 32, at 150-54.

266 See Apple's Answer and Counterclaim at 2-3, Epic v. Apple, No. 4:20-cv-05640-YGR (N.D. Cal. Sep. 8, 2020); Apple Inc. v. Pepper, 139 S. Ct. 1514, 1519-20 (2019).

267 See HoVENKAMP, supra note 8, at 356-58; supra Section IV.A.1.

268 Apple's negotiation of lower fees with a select group of app developers, including Amazon, does count as discrimination, however. See Apple Halved App Store Fee to Get Amazon Prime Video on Devices, BloOMBERG.COM (Jul. 373, 2020), https://www.bloomberg.com/news/articles/2020-07-29/apple-considered-taking-40-cutfrom-subscriptions-emails-show. Whether the discrimination passes muster should depend upon whether attracting those developers, or the integrations with iPhone they provide in exchange for the discounts, improve Apple's overall iPhone product. See id.
} 
cases. $^{269}$

g. Facebook

Proving consumer harm will be a challenge for the FTC in its monopolization case against Facebook. ${ }^{270}$ The FTC alleges that Facebook discriminated against rival social media companies by supplying friend lists to itself but not to those companies, which need them to facilitate adoption by new users. ${ }^{271}$ Facebook does appear to control an essential inputadoption is likely to be very slow if new users cannot invite their Facebook friends to join new social media apps-and Facebook does appear to have monopoly power in the downstream social media market. ${ }^{272}$ The trouble is that social media improves the more people use it, and the more people use rival social media apps, the less they use Facebook. ${ }^{273}$ Thus Facebook will be able to argue convincingly that discriminating against rivals made Facebook better. ${ }^{274}$

\section{Predatory Pricing}

Seeing exercises of power in terms of discrimination in the supply of inputs also helps in the analysis of predatory pricing claims, a perennial source of confusion in antitrust. ${ }^{275}$ These claims are sometimes classified as a kind of monopolization claim, but are best understood as freestanding claims brought under Section 2 of the Sherman Act, because they have formally quite different elements. ${ }^{276}$ To win a predatory pricing claim, a plaintiff must show pricing below average variable cost plus a dangerous probability that the firm will be able to recoup its losses from the below-cost pricing in the future. ${ }^{277}$ Despite this formal distinctness, however, predatory pricing is just another example of discrimination in the supply of inputs.

A firm with access to cash or low-cost financing can choose when in a

\footnotetext{
${ }^{269}$ Cf. Woodcock, Digital Monopoly without Regret, supra note 119, at 56-58.

${ }^{270}$ See Complaint for Injunctive and other Relief, FTC v. Facebook, Inc., No. 1:20-cv-03590 (D.D.C. 2021).

${ }^{271}$ See id. at 42-46.

${ }^{272}$ See Subcommittee on Antitrust, Commercial, and Administrative Law of the Committee on the Judiciary of the United States House of Representatives, supra note 72, at 134-41.

${ }^{273}$ See Morton \& Dinielli, supra note 73, at 11, 15-16.

${ }^{274}$ Cf. Woodcock, Google and Shifting Conceptions of What It Means to Improve a Product, supra note 77.

275 See HovENKAMP, supra note 8, at 443-44.

${ }^{276}$ See id. at 443.

277 See Brooke Grp. Ltd. v. Brown \& Williamson Tobacco Corp., 509 U.S. 209, 223-25 (1993).
} 
product's lifecycle to take profits and when to take losses, borrowing against itself or a bank in order to charge low prices in some periods and then using high prices in other periods to repay the loan. ${ }^{278}$ Such profit-shifting activity changes the nature of the product that the firm sells in ways that can disadvantage competitors, for competitors that are unable to shift profits may be unable to match the low prices charged by the firm, leading consumers to abandon them. ${ }^{279}$ The ultimate source of this competitor harm is discrimination in the supply of inputs. The access to financing of the firm that engages in profit shifting is an essential input to the downstream market in which the firm competes. The firm supplies cash or financing to itself, but not to its competitors, placing them at a disadvantage if they are unable to secure financing from other sources, as shown in Figure 6.

\section{Input}

\section{Consumers}

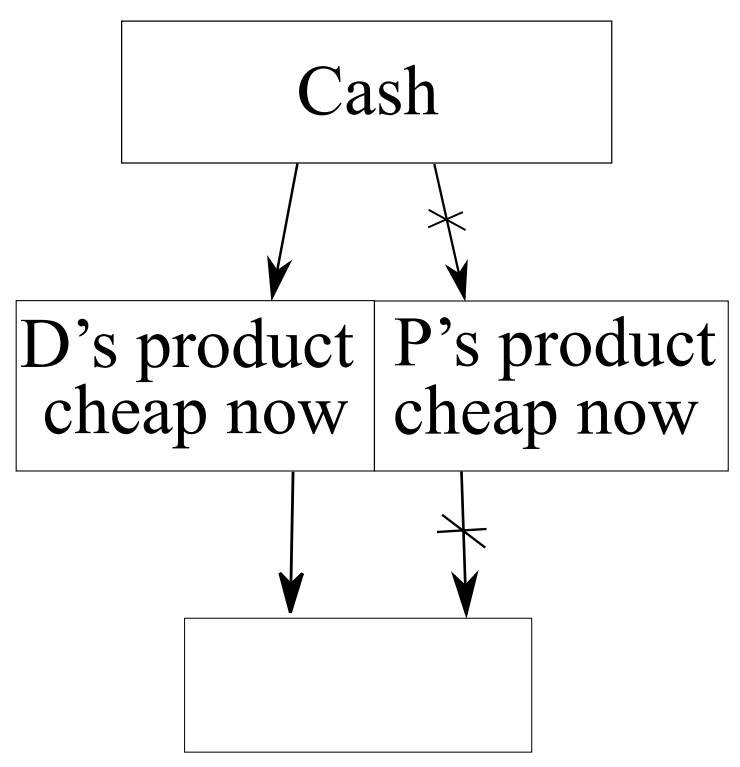

Figure 6

Whether this should count as monopolization then depends on whether the ability to shift profits improves the product. ${ }^{280}$ The answer of the courts has been that it does not, and so they have vowed to condemn below-cost pricing whenever the existence of a dangerous probability of recoupment suggests that it is part of a scheme to shift profits around temporally (for that

278 The analogue of this in the macroeconomic context is consumption smoothing by households. See Jonathan Gruber, Public FinANCE AND Public Policy 304 (2005).

279 See HovenKAMP, supra note 8, at 454-55.

${ }^{280}$ See supra Section IV.A.2. 
is what it means to condemn below-cost pricing only when there is a dangerous probability of recoupment later on). ${ }^{281}$ The absence of a requirement of proof of monopoly power, either with respect to the financing input or in the downstream market, is a peculiar omission in the law. ${ }^{282}$ For predatory pricing to be an exercise of power, it must result from control by the predatory pricer of the financing input, something that courts ought to verify before allowing a case to proceed.

\section{Exclusive Dealing, Microsoft, and Google}

All the examples of monopolization considered so far involve the discriminatory sale of inputs by an input controller that itself competes in the downstream market into which the input controller supplies inputs. Monopolization claims can also be brought against input controllers that do not themselves own downstream operations but which instead use discrimination to favor downstream firms that they do not own but which give them favorable terms or otherwise fit their vision regarding the kind of firms they want in the downstream market. ${ }^{283}$ When the input controller acts pursuant to an agreement with a downstream firm that the controller does not own, no matter how informal the agreement, the case can be brought under Section 1 of the Sherman Act, which prohibits the use of agreements "to restrain trade," as well as under the law of monopolization grounded in Section $2 .{ }^{284}$ For cases brought under Section 1 , the courts apply a variety of tests, many of which are variations on the monopolization test.

Perhaps the most familiar of these variations to the student of the law of monopolization is the test for exclusive dealing. ${ }^{285}$ Exclusive dealing is properly defined as any agreement between an input supplier and the downstream firm pursuant to which the input supplier promises to discriminate against the downstream firm's competitors in supplying them with inputs. ${ }^{286}$ But in practice courts can have trouble seeing any agreement that does not bring about an outright refusal to sell to competitors as

\footnotetext{
${ }^{281}$ See Brooke Grp. Ltd. v. Brown \& Williamson Tobacco Corp., 509 U.S. at 223-25.

${ }^{282}$ See HOVENKAMP, supra note 8, at 455 (noting that courts have "largely ignored structural issues"); but see id. at 467-69 (listing cases in which courts have seemed to take market share into account and conflating the recoupment requirement with proof of monopoly power).

${ }^{283} C f$. AREEDA \& HOVENKAMP, supra note 7, II 770 (arguing that mere discrimination, absent integration in to the downstream market, is not actionable, but only in the context of "arbitrary" refusals to deal not motivated by economic considerations).

${ }^{284} 15$ U.S.C. $\S \S 1,2$ (2018).

${ }^{285}$ See HovenKAMP, supra note 8, at 563-64.

${ }^{286} \mathrm{Cf}$. id. at $571-75$.
} 
exclusive dealing, as the name suggests. ${ }^{287}$ The courts apply a "rule of reason" test to exclusive dealing that is almost identical to the monopolization test, in that it requires a showing of discriminatory behavior (the agreement to deny inputs to competitors, or otherwise to discriminate against them), consumer harm in the form of a showing that the agreement does not improve the quality of the products sold downstream to consumers, and power in the downstream market in which competition is harmed. ${ }^{288}$ Here, however, as when the rule of reason is used against acquisitions of power, the power requirement is called a "market power" requirement rather than a "monopoly power" requirement and is weaker than under the monopolization test: a $35 \%$ market share will do. ${ }^{289}$

In exclusive dealing cases, the courts also consider the extent to which the conspiring firms control the input with a formality and care not seen in the law of monopolization. ${ }^{290}$ The courts measure the share of the input market controlled by the conspiring firms, which they call the share of the input "foreclosed" to downstream competitors, and use that share as a rough proxy for the extent to which the exclusive dealing could have harmed competitors, sometimes even treating a large foreclosure share as triggering per se treatment for exclusive dealing, allowing condemnation of the agreement without a showing of power in the downstream market. ${ }^{291}$ Thus in the foreclosure concept one encounters in the law of exclusive dealing a more rational approach to power measurement than one encounters in the law of monopolization, with its exclusive focus on proof of power in the downstream market, as an input controller's exercise of power is made possible by its control over the input market, not by its control over the downstream market. ${ }^{292}$

Exclusive dealing lay at the heart of the United States v. Microsoft Corp. ${ }^{293}$ case two decades ago, just as it lies at the heart of the government's case against Google today, albeit with very different implications. ${ }^{294}$ In both cases, the input was default status on devices - in Microsoft it was default status for web browsers on PC computers and for Google it was default

\footnotetext{
${ }^{287}$ See id. at 563-64.

${ }^{288}$ See id. at 623-28.

289 See 1 ABA SECTION OF ANTITRUST LAW, supra note 44, at 66.

${ }^{290}$ See HoVENKAMP, supra note 8, at 571-75.

${ }^{291}$ See Standard Oil Co. of Cal. v. United States, 337 U.S. 293, 309-14 (1949); HovENKAMP, supra note 8, at 571-75.

292 See supra Section IV.B.1.

${ }^{293}$ United States v. Microsoft Corp., 253 F. 3d 34 (D.C. Cir. 2001).

${ }^{294}$ Complaint, United States v. Google LLC, No. 1:20-cv-03010 (D.D.C. 2020). I thank Sam Weinstein for pointing out to me the crucial role of exclusive dealing in the Microsoft case.
} 
search status on smartphones. ${ }^{295}$ In both cases, the defendant contracted with equipment manufacturers to deny default status to rivals-Netscape in Microsoft and rival search engines in United States v. Google LLC. ${ }^{296}$ Both had monopoly power in the downstream market. Microsoft had a large share of the PC operating system market, in which Netscape's browser was taken to be a nascent competitor because the browser could evolve one day to run apps, and Google had a large share of search advertising. ${ }^{297}$ And both used the contracts to foreclose much of the input market: Microsoft tied up virtually all PC makers and Google almost all smartphone makers. ${ }^{298}$ But consumer harm was present in Microsoft whereas it is elusive in Google.

In both Microsoft and Google, the product improves with usage. The more people use Windows, the more apps developers write for Windows, and the better Windows becomes. ${ }^{299}$ The more people run Google searches, the more people a Google search ad can reach and the more information Google can use better to target the ad, pleasing Google's advertiser customers. $^{300}$ But in Microsoft, the exclusive dealing could not have improved the product because all Netscape users were also simultaneously Windows users, as Netscape was an application that ran on Windows. ${ }^{301}$ So driving Netscape from Windows could not have increased Windows usage and therefore could not have improved Microsoft's product. ${ }^{302}$ But a user who runs a Google search does not also run a search on a competing search engine, so Google's use of exclusive dealing contracts to channel users to its engine and away from others' does improve Google's search advertising product and so should be immune to antitrust condemnation. ${ }^{303}$

4. Tying

${ }^{295}$ See United States v. Microsoft Corp., 253 F. 3d at 59-64; Complaint at 3-7, United States v. Google LLC, No. 1:20-cv-03010.

${ }^{296}$ See United States v. Microsoft Corp., 253 F. 3d at 59-64; Complaint at 3-7, United States v. Google LLC, No. 1:20-cv-03010.

${ }^{297}$ See United States v. Microsoft Corp., 253 F. 3d at 54-56; Complaint at 3-7, United States v. Google LLC, No. 1:20-cv-03010.

${ }^{298}$ See United States v. Microsoft Corp., 253 F. 3d at 54-56; Complaint at 3-7, United States v. Google LLC, No. 1:20-cv-03010.

${ }^{299}$ See United States v. Microsoft Corp., 253 F. 3d at 55-56.

300 See Complaint at 13-14, United States v. Google LLC, No. 1:20-cv-03010; Woodcock, Google and Shifting Conceptions of What It Means to Improve a Product, supra note 77.

${ }^{301}$ See United States v. Microsoft Corp., 253 F. 3d at 53; Woodcock, Google and Shifting Conceptions of What It Means to Improve a Product, supra note 77.

${ }^{302}$ Cf. United States v. Microsoft Corp., 253 F. 3d at 55-56.

303 See Complaint at 13-14, United States v. Google LLC, No. 1:20-cv-03010; Woodcock, Google and Shifting Conceptions of What It Means to Improve a Product, supra note 77. 
If the exclusive dealing test is the most familiar of the contract-based variations on monopolization, the test used in tying cases is perhaps the least familiar, even though at heart tying represents the discriminatory supply of an input to the same extent as do all exercises of power. But on its face tying nevertheless appears to be something different: it is the act of refusing to sell two products separately, and of insisting instead that the two products be purchased together. ${ }^{304}$ If the seller has control over one of the two products, then buyers for whom the first is essential will be forced to buy the second, and if most buyers of the second need the first, then other firms that sell the second will lose business and may even be driven from the market for the second product. ${ }^{305}$ Tying appears, then, to be a method of harming competitors in the market in which the tyer does not have control. ${ }^{306}$ Antitrust has accordingly developed a test for tying pursuant to which (1) bundling of (2) two separate products (3) in one of which (the "tying product market") the firm has "appreciable economic power" and (4) in the other of which (the "tied product market") the tie will affect a "substantial volume of commerce" results in antitrust liability. ${ }^{307}$

Courts and commentators have for years sensed that there is a rough identity between tying and exclusive dealing, and courts have accordingly signaled a desire to bring tying under the rule of reason approach used for exclusive dealing, but they have never quite been able to define the identity clearly. ${ }^{308}$ The key is to recognize that the market for the bundled product does not come into existence for the first time when a firm first institutes the tie. Instead, the market for the bundled product always exists, regardless whether firms tie their products together or sell them separately. That is because a tie can harm competitors in the tied market only to the extent that consumers bought and consumed both the tying product and the tied product or a close substitute separately before the tie. ${ }^{309}$ Only then can a tie deprive competitors in the tied product market of customers by inducing customers who must consume both products to stop buying the tied product from competitors and start buying it from the firm that institutes the tie. ${ }^{310}$ It follows that the market in which competition is harmed by the tie is not the market for the tied product, but rather the market for the bundle, for as a result of the tie buyers who once purchased the tying product from the tier and the tied product from competitors are now compelled to buy both from

\footnotetext{
${ }^{304}$ See HOVENKAMP, supra note 8, at 517-19.

${ }^{305}$ See id.

${ }^{306}$ See id.

${ }^{307}$ See id.

${ }^{308}$ See GAVIL ET AL., supra note 18, at 976.

${ }^{309} \mathrm{Cf}$. HovenKAMP, supra note 8, at 520-21.

${ }^{310} \mathrm{Cf}$. id.
} 
the tier.

In tying the two products together, the tyer engages in the familiar activity of discriminating in the supply of inputs-specifically, engaging in discriminatory denial of inputs - to downstream competitors, as shown in Figure 7. The tying product, which in any tying case must be under the control of the tier, is an essential input into creation of the bundle. ${ }^{311} \mathrm{By}$ refusing to sell the tying product separately to consumers and instead tying it to the tied product, the tier effectively denies competitors in the bundle market access to an essential input. ${ }^{312}$ As in Qualcomm and Lorain Journal, the analysis is complicated by the fact that consumers assemble the bundle themselves before the tie. But the effect of the tie is the same as it would be were the tier to have sold the tying product directly to competitors in the tied product market before the tie, allowing the competitors to bundle the tying product with the tied product themselves and sell the complete bundle to consumers, and then had refused to continue to supply the tying product to competitors but continued to sell the bundle, including the tier's own version of the tied product, itself.

\section{Input}

\section{Tying product}

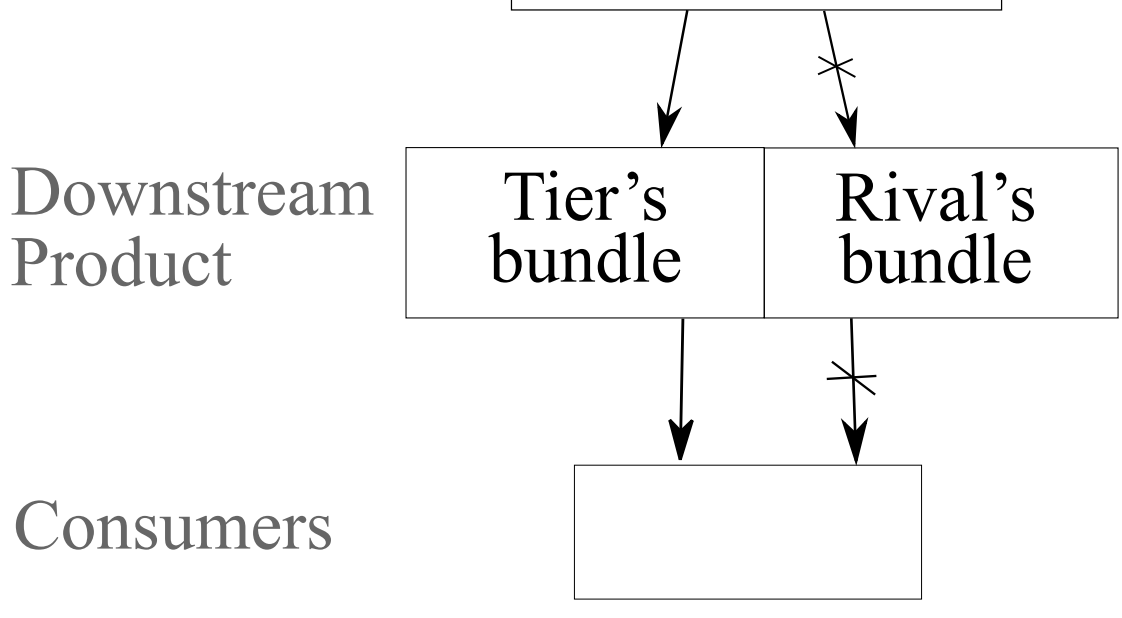

Figure 7

To be sure, a tie does not prevent consumers from still buying the tied

\footnotetext{
${ }^{311}$ See id.

${ }^{312}$ Cf. id.
} 
product from competitors, but doing so is likely to be prohibitively costly for consumers because then consumers must pay for the tied product twice, once as part of purchasing the complete bundle from the tier in order to obtain the tying product and again when purchasing the tied product from the competitor. Tying is in this way a more politic alternative to the refusal to sell to customers who do business with a competitor that was on display in Lorain Journal. ${ }^{313}$ Rather than explicitly refusing to sell to those who do business with others, the input controller can achieve the same result more subtly by bundling all of its components together and refusing to sell the input separately to anyone, rather than only to those who buy from others. ${ }^{314}$ The effect is equally discriminatory, but the policy is facially neutral. ${ }^{315}$

As just another form of discrimination in supply, tying cases can be brought as monopolization cases under Section 2 or, when the tie is imposed pursuant to an agreement between a favored tied product seller and the controller of the tying product, tying cases can be brought under Section 1 as exclusive dealing cases, since tying is indistinguishable from exclusive dealing once it is understood to be discrimination in input supply. ${ }^{316}$ If brought as exclusive dealing, the rule of reason, including the foreclosure concept, would apply. ${ }^{317}$ Because the tying product is the input, the foreclosure inquiry would focus on the tying product market, tracking the current four-factor tying test described above, which requires a showing of power in the tying product market. ${ }^{318}$ But the rule of reason would diverge from the four-factor tying test in requiring a showing of market power in the market for the bundled product, whereas the current tying test requires only a vague showing of some amount of power in the tied product market, rather than in the market for the bundled product. ${ }^{319}$ The focus of the four-factor test on tied market power reflects tying law's current failure to understand that the market in which competition is harmed in tying is the market for the bundled product. The tied product market is no more relevant to tying than is the market for tires in a case in which the controller of bike frame production refuses to supply frames to competing bike manufacturers. Tires are part of bikes, but they have no bearing on a case involving discriminatory supply of a completely different input into bike production.

\footnotetext{
313 See Lorain Journal Co. v. United States, 342 U.S. 143, 152-56 (1951).

${ }^{314}$ Cf. id.

${ }^{315}$ Cf. id.

316 See HovENKAMP, supra note 8, at 559-60; cf. GAVIL ET AL., supra note 18, at 966-67. Courts sometimes allow tying cases to be brought under Section 1 even when a single firm produces both the tying and tied products. See HoVENKAMP, supra note 8, at 534.

317 See supra Section IV.B.3.

318 See HOVENKAMP, supra note 8, at 517-19.

${ }^{319}$ See id.
} 
The rule of reason also appears to differ from the four-factor tying test in allowing a plausible product-improvement rationale to defeat liability. ${ }^{320}$ But here the difference is more apparent than real. This consumer harm requirement in fact already exists in tying in latent form as the requirement that the tying and tied products be separate products sold in separate markets. $^{321}$ That requirement immunizes from the traditional tying claim products that are physically always tied together, such as two components of a smartphone that are hardwired together inside the case. ${ }^{322}$ The requirement also immunizes products that have never been sold separately in the past, whether they are physically separable or not. ${ }^{323}$ If the requirement of separate markets is not to be understood as a consequence of a purely arbitrary desire to preserve ties that are hardwired into technology or that show longevity, then the requirement must be understood to attempt to proxy for product improvement. Ties that appear to be necessary for a device to function, or that have stood the test of time, are more likely to be genuine product improvements, even if they do not always turn out to be such. ${ }^{324}$ Thus the rule of reason's consumer harm requirement makes more explicit a search for product improvements that also appears in the traditional test. ${ }^{325}$ In recent years, the courts have seemed ready to abandon the four-factor tying test; the proper way to do that is to replace it with the exclusive dealing test, being careful to measure market power in the market for the product bundle, rather than in the tied product market. ${ }^{326}$

\section{Intrabrand Restraints}

The law of intrabrand vertical restraints applies to conduct that often appears facially neutral but which, like tying, has a disparate impact. ${ }^{327}$ And like tying, this facial neutrality seems to have confused courts into applying a test that differs from the standard monopolization test, even though at heart intrabrand vertical restraints are just another form of discrimination in input supply.

Intrabrand vertical restraints are agreements between manufacturers, which play the role of input suppliers, and the retailers that sell their products,

\footnotetext{
${ }^{320}$ See id. at 559-61, 571-75.

${ }^{321}$ See id. at 537-43.

${ }^{322}$ See id.

${ }^{323}$ See id.

${ }^{324}$ See id.

325 See id. at 517-19.

326 See Jefferson Parish Hospital Dist. No. 2 v. Hyde, 466 U.S. 2, 34-35 (1984);

HOVENKAMP, supra note 8, at 559-61.

327 See HoVENKAMP, supra note 8, at 579-80.
} 
which play the role of downstream firms. ${ }^{328}$ These agreements often differ from agreements between input suppliers and downstream firms in other contexts because the manufacturer negotiates the agreements with all of the downstream firms in the downstream market, rather than just with a favored firm, as in a classic exclusive dealing case. ${ }^{329}$ A manufacturer might ask all retailers of its products to abide by certain display standards, to sell above minimum prices, or to meet certain sales targets on penalty of termination. ${ }^{330}$ The rules imposed on retailers are usually facially neutral-they apply equally to all - but they have a disparate impact, causing those less able to comply with the rules to face a denial of access to the input or higher costs, to the benefit of those better able to comply. ${ }^{331}$

One reason the rule of reason test applied in exclusive dealing cases is not applied in intrabrand restraints cases may be that the facial neutrality of the terms that manufacturers often impose on retailers makes it difficult to apply the rule of reason's market power requirement. ${ }^{332}$ When terms are applied equally to all retailers, the identity of the favored firms that should be counted in the market share calculation is not always immediately evident. ${ }^{333}$ By contrast, in an exclusive dealing case in which the input controller contracts with only one downstream firm, it is clear that the downstream contracting party is the favored party and so that firm's market share should be used to determine market power. ${ }^{334}$ To avoid this problem, courts appear to dispense with the market power requirement in intrabrand vertical restraints cases involving facially neutral terms imposed on all retailers. ${ }^{335}$ But they appear to retain the foreclosure analysis found under the rule of reason in exclusive dealing cases, but call it market power. ${ }^{336}$ What remains in intrabrand restraints cases is a test that requires proof of discriminatory conduct and foreclosure, combined with a focused inquiry into whether the restraint improves the product. ${ }^{337}$

\section{Vertical Mergers}

The law of monopolization and exclusive dealing provides a framework

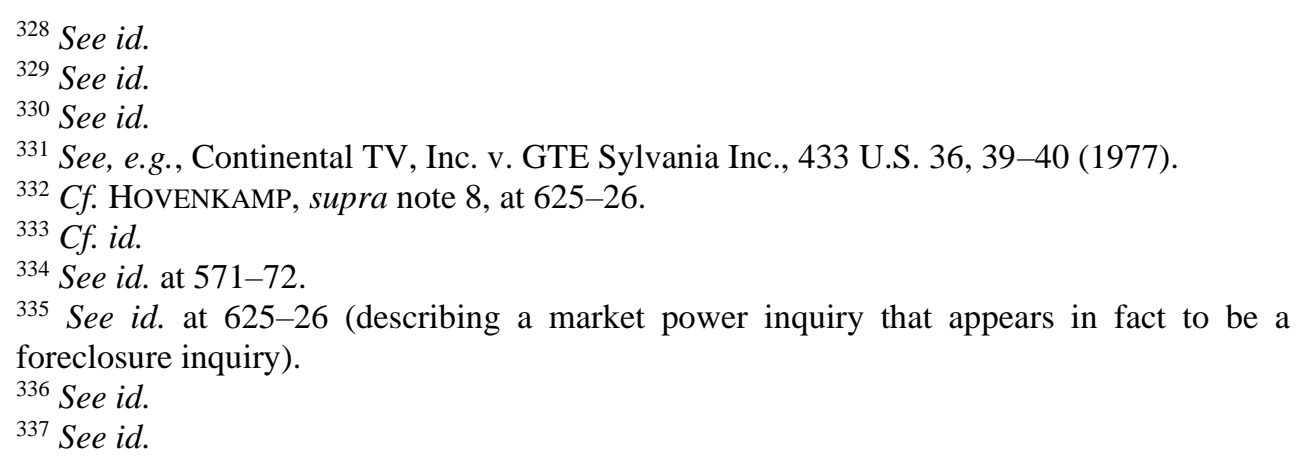


for antitrust treatment of a practice that antitrust has struggled to evaluate in recent years: the vertical merger. ${ }^{338}$ An input controller that already happens to own downstream operations might use discrimination to favor those operations, if doing so would expand profits. ${ }^{339}$ But an input controller that lacks downstream operations will discriminate only if some downstream firms might be induced by the discrimination to behave as the input controller wishes. ${ }^{340}$ If downstream firms cannot be manipulated in this way, then the controller might try to use an agreement to sharpen the message sent by the discrimination. ${ }^{341}$ If that fails, however, then the last recourse of the input controller is to buy a downstream firm and use the control rights incident to ownership to force the downstream firm to do what the input controller wants. ${ }^{342}$ Any concomitant discrimination in supply directed at downstream competitors now serves only the purpose of clearing out noncompliant firms from the market and not of sending a signal to more-compliant firms about how to behave. Clearly, then, vertical merger facilitates monopolization, even if strictly speaking it does not become monopolization unless the merged firm actually discriminates in the supply of inputs to the remaining independent downstream firms. ${ }^{343}$

The courts have long held Section 7 of the Clayton Act to prohibit mergers that inflict no more than an incipient harm to competition, and so it would be appropriate for antitrust to block vertical mergers that facilitate monopolization, so long as they do not improve the downstream product. ${ }^{344}$ The test to apply is the rule of reason test used in exclusive dealing cases. ${ }^{345}$ Courts should consider the share of the input controlled by the merging firms - the foreclosure requirement - as well as the share of the downstream market controlled by the merging firms - the market power requirement, applied only for the sake of consistency - and whether the merger improves the product. ${ }^{346}$ The fact that the merged firm may not actually discriminate in supply is irrelevant, as the incipiency standard permits courts to take seriously the danger that the merged firm might do so. ${ }^{347}$ Thus the requirement of proof of discriminatory conduct should be dropped from the

\footnotetext{
${ }^{338}$ See United States of America v. AT\&T, Inc., No. 17-2511, slip op. at 1038-47 (D.D.C. Jun. 12, 2018).

339 See AREEDA \& HOVENKAMP, supra note 7, II 755.

${ }^{340} \mathrm{Cf}$. id. II 770.

${ }^{341}$ See infra Sections IV.B.3, IV.B.4, IV.B.5.

342 See HovenKAMP, supra note 8, at 505-11.

${ }^{343}$ See supra Section IV.A.3.

34415 U.S.C. $\$ 18$ (2018); GIFFORD \& KUDRLE, supra note 89, at 28.

345 See supra Section IV.B.3.

${ }^{346}$ See supra Section IV.B.3.

${ }^{347}$ See Brown Shoe Co. v. United States, 370 U.S. 294, 318 n.32 (1962).
} 
test as applied to vertical mergers.

\section{A Gap}

It is unlikely that current law would prohibit an input controller from discriminating in favor of downstream firms that the controller does not own and with which the controller has no contractual relationship. ${ }^{348}$ The law of monopolization requires proof of monopoly power in the downstream market. ${ }^{349}$ That seems to imply that the input controller must own a firm that operates in the downstream market, although it is possible that it would permit the power of the favored firm to substitute for the power of downstream operations owned by the input controller. ${ }^{350}$ The laws of vertical contracting appear even more completely to rule out liability for favoring an independent downstream firm, for the laws of vertical contracting all of course require an agreement, at least informal, between the favored firm and the input controller. ${ }^{351}$ Theory, however, does not distinguish between agreements, formal ownership, and mere favoritism. So long as there is discrimination in the supply of inputs by an input controller, and there is not accompanying product improvement, there should be liability.

\section{CONCLUSION}

Scholars and the courts have long struggled to identify the purposes of antitrust in the vague language of the antitrust statutes. Is antitrust's goal to smash bigness $?^{352}$ Is it to raise the average wage $?^{353}$ Or to protect the political system against wealthy economic actors $?^{354}$ If we look for coherence in the doctrine and practice of more than a century of antitrust in the United States, the answer to all of these questions is "no," though antitrust may incidentally advance these goals at times. Instead, if there is a theory immanent in the antitrust experience, it is the theory that antitrust is the only field of law devoted exclusively to the regulation of private power, its acquisition and its exercise, through input control. All power flows ultimately from one source,

\footnotetext{
${ }^{348}$ See AREEDA \& HOVENKAMP, supra note 7, II 650c.

${ }^{349}$ See supra Section IV.B.1.

${ }^{350} \mathrm{Cf}$. AREEDA \& HOVENKAMP, supra note 7, II 650c.

${ }^{351}$ But see HOVENKAMP, supra note 8, at 534 (discussing the agreement requirement for tying).

352 See Tim Wu, The CurSe of Bigness: ANTITRuST IN THE New GiLdEd Age (2018).

${ }^{353}$ See Suresh Naidu et al., Antitrust Remedies for Labor Market Power, 132 HARV. L. REV. 536 (2018).

354 See Rudolph J. R Peritz, COMPetition Policy IN AMERICA, 1888-1992: History, RHETORIC, LAW. (2001).
} 
the ability to withhold from others things that they need, which is to say, to deny inputs to them. Antitrust is devoted to the regulation of input control; antitrust decides when it is appropriate for a private person to amass enough control over an input as to be able to deny the input to others and when, having amassed such control, a private person may in fact deny an input to others. Nothing more. But to cast the exercise of power in terms of denials of inputs is already to miss some of the subtlety of antitrust, for outright denials of access are only the most extreme form of the power exercises antitrust regulates. Any discrimination in the supply of inputs, whether explicit or facially neutral but having a disparate impact, represents an exercise of power derived from input control, and is therefore regulated by antitrust: for any discrimination in supply rewards some buyers and punishes others, as we would expect an exercise of power to do.

Antitrust is not so naïve as to believe, however, that there is such a thing as a world without power or its exercise and that antitrust's purpose should therefore be to eliminate power by eliminating all control over inputs or proscribing all discrimination in their supply. ${ }^{355}$ On the contrary, antitrust understands that all production requires both the centralization of control over inputs and discrimination in their supply: no widget can be produced without a firm controlling, to the exclusion of others, some element necessary to its production and denying access to that element to those the firms believes will do a poor job assembling the finished product. Indeed, all production can be conceptualized as being undertaken through vast linear supply chains in which the components of an end product are brought together by being sold along the chain from parts supplier to parts supplier, accumulating a new component at each step until the finished product emerges at the end. The firm that controls all of a particular component-an input - directs how parts are sold along the chain, discriminating in the supply of inputs to steer the product toward some components and away from others. The point along the chain at which this controller chooses to sell on nondiscriminatory terms, either voluntarily or due to competition from other sellers, is the point that defines the boundary of the product: the point at which inputs become an output that is cast onto the market free of its producer's control. It is at such market interfaces that buyers (and not the seller, who is not discriminating in supply) decide how these products are to be recombined with yet further components to make the end product of the supply chain. And so it becomes clear that the problem of discrimination-

355 Cf. Duncan Kennedy, The Stakes of Law, or Hale and Foucault Transformative Discourses in Postmodern Social Cultural and Legal Theory, 15 LEGAL STUD. F. 327, 35362 (1991) (criticizing Foucault for failing to appreciate that power is an inherent part of legal relations and not an artificial imposition of the state). 
the exercise of power-is actually the problem whether an input controller should decide which components should go into an end product or whether buyers - and ultimately the end consumer, who is the ultimate buyershould decide. Antitrust recognizes that consumers cannot decide all; they do not want to know which transistor should go where in the iPhone. But antitrust also recognizes that consumers may want to decide some.

The guiding principle antitrust follows to determine when discrimination in input supply, and the acquisition of control over inputs that makes it possible, is acceptable is that of produce improvement. The acquisition and exercise of power are acceptable when these improve the end product enjoyed by consumers, in the sense of making the product more desirable to them. Sellers can have power when they use it to make better products, otherwise not; that is the fundamental law of antitrust. It is a law that picks winners, that respects power when power produces according to the sense of judges regarding what consumers want, and it is a law that smashes power when power fails to deliver. And the fact that power can sometimes fail to deliver goes without question in antitrust. Firms can get rich by improving products, which gives them a motive to do good. But they can also get rich by spying on their customers to the end of learning whether they can charge them higher prices, or by using power to crush customers who insist on better trading terms. In these cases products are not improved, and the jimmying with the supply chain required to spy and to smash may well reduce product quality, instead of improving it.

Antitrust's laws governing agreements and mergers between competitors are largely directed at regulating the acquisition of power: the centralization of control over inputs. ${ }^{356}$ Antitrust's laws governing single firm conductthe law of monopolization - as well as the laws of vertical contracting and vertical merger, are largely directed at regulating exercises of power, meaning discrimination in the supply of inputs. ${ }^{357}$ But the antitrust laws carry out these missions imperfectly, as they are only dimly aware of the fundamental importance of input control. In particular, the parts of the antitrust laws directed at the exercise of power - the laws of monopolization and vertical contracting - either fail to test for power at the right level of the supply chain or affirmatively require that power be tested at the wrong level. To establish that a firm has the requisite control over inputs to be able to exercise power, the focus must be on power in the input market, but the law of monopolization generally requires proof of power only in the downstream market in which competition is banned, and the law of vertical contracting generally requires this to, although to its credit it also requires proof of power

\footnotetext{
35615 U.S.C. $\S 1,18$ (2018).

35715 U.S.C. $\$ 2,14,18$ (2018).
} 
in the input market as part of its "foreclosure" inquiry. Apart from the law of intrabrand restraints, antitrust's rules governing power exercise also generally fail to recognize that all discrimination in the supply of inputs, including facially neutral discrimination having a disparate impact, represents an exercise of power, and generally seems to treat only outright denials of access (refusals to deal by single firms or exclusive dealing arrangements between suppliers) as exercises of power. Only by coming to appreciate its own internal coherence can antitrust gather up these loose strand of its practice. 